\title{
Közgazdaságtan a jogalkalmazásban
}

Az elmúlt években a jogalkalmazási közgazdaságtan (forensic economics) megkapta a közgazdasági szakmai körökben hivatalos elismerésnek számító JEL-kódot. A tanulmány e szakterület fogalma tisztázásának szándékával bemutatja a piac- és vállalatelmélet fejlődését és jogalkalmazáshoz való viszonyának változásait. A verseny- és ágazati szabályozásban használt vizsgálatokat, eljárásokat követve felvázolja a jog és közgazdaságtan, a jogászok és közgazdászok közötti kapcsolatokat, végül állást foglal abban a kérdésben, hogy létezik-e jogalkalmazási közgazdaságtan. Journal of Economic Literature (JEL) kód: K13, K21, K23, L40, L51.

\section{Bevezetés}

A verseny szabályozása során, követve az ágazati szabályozás példáját, egyre nagyobb mértékben alkalmaznak közgazdasági elemzéseket. A hatósági eljárások felülvizsgálatával foglalkozó bíróságok is mindinkább támaszkodnak közgazdasági elméletekre és közgazdász szakértőkre. Az amerikai gyakorlatban már elterjedt és Európában is erősödő magánjogi jogérvényesítés egyre több közgazdasági elemzést igényel a versenyjogi ügyekben is. A közgazdasági elemzési eszközök pontosítása, finomítása és az eszközök alkalmazásának módja tekintetében az amerikai versenyszabályozás hoszszabb múltra tekint vissza. Az 1980-as évektől Európában is egyre nagyobb szerepet játszottak a közgazdasági elemzések a versenyszabályozásban, majd a bírói gyakorlatban. A gazdasági hatások következetesebb számbavételét célul tűző uniós versenypolitikai változás egyik jele volt, hogy a Versenypolitikai Főigazgatóságon létrehozták a vezető közgazdász posztját és a munkáját segítő elemző részleget 2003-ban, ami felgyorsította a tagországok szabályozó hatóságainál a hasonló beosztások létrehozásának folyamatát (Neven [2006], Gavil [2007]).

A közgazdasági elemzések szükségességét egyre szélesebb körben ismerték el, hiányát egyre több amerikai és európai bírósági esetben kifogásolták (NevenMano [2009]). A közgazdasági elemzések segíthetnek abban, hogy a pusztán jogi

Valentiny Pál az MTA KRTK KTI tudományos fömunkatársa.

A kézirat első változata 2019. január 20 -án érkezett szerkesztőségünkbe.

DOI: http://dx.doi.org/10.18414/KSZ.2019.2.134 
elöírásokba nem foglalható versenykorlátozó magatartásra is fény derüljön. Az ilyen elemzések azt is figyelembe tudják venni, hogy ugyanaz a piaci magatartás más és más körülmények között különbözö eredményekre vezethet - ami az egyik esetben torzítja a versenyt, az a másikban növeli a hatékonyságot, és innovációt gerjeszt (Gual és szerzőtársai [2005], Neven [2006]).

A verseny- és ágazati szabályozásban, a szabályozó hatósági döntéseket felülvizsgáló bírósági eljárásokban alkalmazott közgazdasági ismeretek döntően a piac- és vállalatelmélet területéről származnak. A kapcsolat azonban kétirányú, az alkalmazás során felmerülő problémák vizsgálata megtermékenyítően hatott a közgazdasági elmélet fejlődésére is. A tanulmányban az alkalmazott közgazdaságtan ezen ágát abból a szempontból vizsgáljuk, hogy a jogalkalmazási közgazdaságtan mennyiben vált önálló tudományterületté, milyen a kapcsolat a jogalkalmazásban használt közgazdasági eszközök és a hagyományos piac- és vállalatelmélet között.

$\mathrm{Az}$ egyszerübb, formai és merev hüvelykujjszabályok alkalmazásán túllépve, a közgazdasági elemzés eszköztára az 1970-es évektől kezdve a versenyszabályozás fontos része lett. Az összejátszás elméleti modelljei például megmutatták, hogy milyen feltételek mellett stabil egy kartell. Ezek a modellek segítették a versenyhatóságokat a "gyanús” iparágak megtalálásában, és hozzájárultak az olyan új versenypolitikai eszközök kialakításához, mint az „engedékenységi” politika (leniency policy - Motta [2007], Motta-Polo [2003]). A fúziók esetében a legnagyobb szerep a várható következmények becslése és a fúziók engedélyezésének feltételeuul szabott kötelezettségvállalás meghatározása terén jut a közgazdászoknak. A monopolizáció megítélésében szintén jelentős szerepet kapnak a közgazdasági elemzések, mint az AT¿T-, Microsoft- vagy a Google-vizsgálatban. ${ }^{1}$

Tanulmányunkban először felvázoljuk, hogyan próbálják a kérdéssel foglalkozó szerzők besorolni a különbözö közgazdaságtani tudományterületeket, milyen helyet találnak a jogalkalmazásban használt közgazdaságtannak. Ezt követően a jogi alkalmazások szempontjai szerint röviden áttekintjük a piac- és vállalatelmélet fejlödését, majd bemutatjuk a piac- és vállalatelmélet szerepét a jogalkalmazásban és azokat a főbb mérföldköveket, amelyeknél a jogi alkalmazások az empíria és az elmélet fejlödését is elősegítették. A tanulmány negyedik részében a jogalkalmazási közgazdaságtan társadalmi beágyazottságának kérdésével, a jogászok és közgazdászok kapcsolatrendszerével foglalkozunk, végül következtetéseket vonunk le.

\section{Fogalmi elhatárolások}

A közgazdaságtannak azt az ágát, amelyet ideiglenesen jogalkalmazási közgazdaságtannak nevezünk, angolul forensic economics néven ismerik. Az elmúlt évtizedekben a fogalom tartalma fokozatosan módosult. A Journal of Economic

\footnotetext{
${ }^{1}$ United States versus ATßT, 552 F. Supp. 131 (D.D.C. 1982) és United States versus Microsoft Corporation 253 F.3d 34 (D.C. Cir. 2001), Statement of the Federal Trade Commission Regarding Google's Search Practices in the Matter of Google Inc. FTC File Number 111-0163, January 3. 2013.
} 
Literature tudományági besorolásában (JEL Classification System) 2013 vége óta szerepel, ${ }^{2}$ a jog és közgazdaságtan kategóriáján belül, a kártérítési jog és a termékfelelösség alcsoportjával közös K13-as kód alatt. A besoroláshoz tartozó útmutató ${ }^{3}$ szerint a kód a kártérítési jog, a termékfelelősség és a jog és közgazdaságtan, illetve a közgazdaságtan metszetében születő tanulmányokat sorolja ide, beleértve az - ebben az értelmezésben inkább igazságügyi közgazdaságtannak ${ }^{4}$ fordítható forensic economicsot is. Hagyományosan a forensic economics a bíróság elé kerülö kártérítési ügyekben a károkozó magatartás felfedését és a kár becslését végző, fizetett szakértők által alkalmazott közgazdasági eszközöket jelenti. A JEL-kategóriák közé való bekerülését és az azon belüli elhelyezését, feltehetően hosszú viták előzték meg, amelyeket majd későbbi kutatások fognak feltárni, ahogy például a mikroökonómia (és makroökonómia) 1990-es önálló megjelenéséről is most születnek az első, az amerikai közgazdasági társaság különböző bizottsági ülésein készített emlékeztetőket feldolgozó beszámolók (Cherrier [2015]).

A JEL-kód megjelenését előrevetítő Zitzewitz [2012] cikk is már a hagyományosnál szélesebb körben foglalkozott a forensic economics mibenlétével, beleértette azokat az akadémiai jellegü tanulmányokat is, amelyek a gazdaság müködésében (vagy működési zavarában) szerepet játszó magatartás jobb megértéséhez hozzásegítenek. Az ezzel foglalkozó közgazdászok gyakran az elsők, akik a gazdasági szereplők által elrejteni kívánt magatartásra és annak kiterjedtségére bizonyítékot találnak. A kifejlesztett eszköztár ügykörönként némileg változhat, mégis univerzális jellegű, a tőzsdei manipulációk, a vállalatvezetői érdekeltségi rendszerek kérdéseitől a vizsgán történő csalásokon át a szükségtelen mütétekig és munkahelyi diszkriminációig terjednek. A Zitzewitz által vizsgált több mint száz tanulmány a hagyományos közgazdaságtan, a forensic economics és a követlen bizonyítékok gyüjtése közötti együttműködést illusztrálja: a közgazdasági elmélet szolgáltatja a rejtett tevékenységekre vonatkozó hipotézist, a forensic economics ezt megerősíti vagy elveti, végül beszerzik a bizonyítékokat (Zitzewitz [2012] 733. o.). A forensic economics szerzői elméleti háttérként az árelmélet mellett elsősorban két Nobel-díjas, Theodore Schultz és Gary Becker fejlödéselmélettel, emberi tőkével, a család szerepével, háztartás-gazdaságtannal foglalkozó müveire hivatkoznak (Zitzewitz [2012], Ireland [1997] 65. o.).

A JEL-kódrendszer $K$ betűje 1990 óta a jog és közgazdaságtan müvelőinek van fenntartva, a forensic economics kérdéseivel foglalkozók számára mindig is fontos volt, hogy tisztázódjon tudományterületük és a jog és közgazdaságtan viszonya. A jog és közgazdaságtan kapcsolódását - vagy a jog közgazdasági elemzését - szokás a skót felvilágosodás szerzőiig visszavezetni, modern kori kezdeteit pedig a Journal of Law and Economics folyóirat 1958-as megjelenéséhez kötni (Mackaay [2000]). Ezzel szemben a forensic economics témájával - bár az ebbe a körbe sorolható tevékenység régóta folyhatott - mint tudományos elfoglaltsággal a National Association of Forensic Economics (NAFE) 1986-os megalakulásától, illetve az általuk 1987

\footnotetext{
${ }^{2}$ A lehetőséget Eric Zitzewitz cikke már 2012-ben beharangozta (Zitzewitz [2012]).

${ }^{3}$ Az American Economic Association honlapján érhető el: https://www.aeaweb.org/jel/guide/jel.php.

${ }^{4}$ A bíróságok működésével, jogi vizsgálatokkal összefüggő közgazdaságtan, amely a bíróságok elötti tanúsítást, a szakértelmen alapuló vitára való készséget is magában foglalja.
} 
óta kiadott Journal of Forensic Economics megjelenésétől számolnak. A forensic economics a jog és közgazdaságtan négy nagyobb kérdésköre: a tulajdonjog, a büntetőjog, a szerződési jog és a kártérítési jog közül az utóbbi kettővel áll szorosabb kapcsolatban, de az átfedések kisebbek, mint gondolnánk (Ireland [1997] 67. o.). A forensic economics elsősorban a méréssel és a bizonyítékokkal összefüggő kérdésekre helyezi a hangsúlyt, míg a jog és közgazdaságtan döntően tudományos jellegü tevékenységeket ölel fel, és művelői jellemzően nem vállalnak bírósági eljárásokban térítéses részvételt. A jog és közgazdaságtan kérdéseivel foglalkozók nem törekedtek önálló szakmaként elismertetni magukat, ami a hagyományos forensic economics terén kezdettől fogva jellemző volt. További megkülönböztető vonás, hogy míg a jog és közgazdaságtan körülhatárolható kutatási programmal rendelkezik, addig a forensic economics sokféle, szétszórt jogi és közgazdasági területtel érintkezik, emiatt nem hozott és nehezen is hozhat létre egységes kutatási koncepciót (Lianos [2012] 5. o.). A hagyományos forensic economics első tíz évét áttekintő elemzésében Ireland [1997] megemlíti, hogy létezik ugyan a versenyjog területén az oksági viszonyokat közgazdasági elemzői eszközökkel vizsgáló törekvés, de művelői oly kevesen vannak, hogy nem érdemes cikkében foglalkozni velük (64. o.).

Nem lehet eldönteni, hogy a létszám nőtt-e meg, a szándék lett-e erősebb, vagy mindkettő, de két évtizeddel később, 2008-ban, a négy évvel korábban létrehozott Journal of Competition Law \& Economics egy teljes száma (Vol. 4. No. 1.) nyolc cikkben foglalkozott a piac- és vállalatelmélet (industrial organization, IO) specializált részterületének, a forensic industrial organizationnek (forensic IO) a meghatározásával. A tanulmányok közül Connor [2008] a forensic szó latin eredetéből ${ }^{5}$ kiindulva, úgy véli, hogy a forensic economics a kormányzat számára készített, nyilvánosan hozzáférhető közgazdasági elemzést jelöl, ahol a kormányzaton a hatóságokat (verseny, szabályozó) és az igazságszolgáltatást érti. Mivel a hatóságok és az igazságszolgáltatás eljárásai tényeken alapulnak, ezért - mondja Connor - a forensic economics is alapvetően, bár nem kizárólag, empirikus jellegü (31. o.).

A nyolc cikket felvezető, programadónak tekinthető Schinkel [2008] írás kísérletet tesz az általa vizsgált forensic $I O$ müködési területének meghatározására és tudományos besorolására. ${ }^{6}$ Schinkel szerint a forensic $I O$ az elméleti és empirikus piac- és vállalatelmélet közgazdasági eszköztárának alkalmazását jelenti a versenyjog érvényesítésének különböző stádiumaiban. A forensic IO így szűkebb területet ölel fel, mint a piac- és vállalatelmélet, amely maga is csak részben kötödik a versenyjoghoz.

A gyakran használt versenyjogi közgazdaságtan (antitrust economics) ${ }^{7}$ fogalma még szükebb területtel foglalkozik, mint a forensic $I O$, mert elsősorban a versenyjog közgazdasági interpretációjára, nem pedig azoknak a közgazdasági eszközöknek és módszereknek a használatára koncentrál, amelyekkel a versenyjog érvényre

\footnotetext{
${ }^{5}$ A latin forensis a forum szóból származik, jelentése: a piacon történő, szinonimája a publicus. Mivel a jogszolgáltatással összefüggő ügyek egy része a forumon zajlott, a forensis a nyilvánosságot, a nyilvánosság előtt zajlót, egyben az ott megvitathatót is jelentette.

${ }^{6}$ Lianos [2012] is elfogadja a forensic IO szóhasználatot, és a forensic economics alá sorolja be.

${ }^{7}$ Európában, ahol az antitrust helyett a competition policy jelenti a versenyszabályozást, az antitrust economics helyett a competition economics kifejezést használják.
} 
jutását segítik (uo. 3-4. o.). A forensic IO leginkább azzal járul hozzá a versenyjogi esetek tisztázásához, hogy segít megállapítani az oksági kapcsolatokat az észlelt jelenségben, magatartásban. Ez akkor sikerülhet, ha a vizsgált ügyre vonatkozó releváns elméletből kiindulva tesztelhető hipotéziseket fogalmaznak meg, és azokat, ha mód van rá, az ökonometria eszköztárával tesztelik. A Daubert-ügyben ${ }^{8}$ a bizonyítékok használatát és a szakértők részvételét szabályozó kritériumok - mondja Schinkel - éppen ezt követelik meg, a világosan felvázolt oksági kapcsolatok elfogadott tudományos eszközökkel való bemutatását. ${ }^{9}$

Ha a szóhasználat eredetét kutatjuk, akkor azt látjuk, hogy a forensic economics kifejezés talán az US versus IBM üggyel ${ }^{10}$ összefüggésben bukkant fel először. Az ügy IBM-nek kedvező lezárását követően a céget képviselő szakértők könyvben foglalták össze a per tanulságait. A könyvről és hátteréről készült alapos recenzió címében lehetett először a forensic economics kifejezéssel találkozni. A recenzió szerzője éppen a szó latin eredetének megfelelően - a jogi, bírósági eljárásban, a tárgyalóteremben zajló és az ott lévő körülményekhez, hallgatósághoz, bírói felkészültséghez alkalmazkodó - közgazdasági érvelés körülírására idézőjelesen használta a kifejezést (Boudin [1984] 836. o.). Az idézőjeles használat ellenére, vagy éppen ezért, a recenzens - aki egyébként bíró - jó érzékel ragadta meg, hogy a közgazdasági elemzésnek bizonyos értelemben önállósuló változatával, kifejezetten a jogalkalmazás céljára formált közgazdasági gondolatokkal és eszköztárral találkozott.

Az eddigiek alapján három, párhuzamosan építkező és egymással kevés kapcsolatot felmutató alkalmazott közgazdasági vonulatot láthatunk. A versenyügyekben közreműködő közgazdászok a forensic szó eredeti értelmében a forensic economics területéhez tartoznának, de ezt a szókapcsolatot a különböző típusú kártérítési ügyekkel foglalkozó közgazdászok lefoglalták, elméleti hátterüket inkább a jog és közgazdaságtan táján keresték. A szerzők egy másik, gyarapodó csoportját az köti össze, hogy a gazdasági szereplők rejtett magatartásait próbálják felderíteni, függetlenül ennek jogi következményeitől. A harmadik csoportba a versenyjog területén dolgozó közgazdász szakértők kerülnek, akik a piac- és vállalatelmélet (IO) alapján, annak empirikus alkalmazásait használva vesznek részt a jogérvényesítés folyamatában. A továbbiakban a piac- és vállalatelmélet fejlődését az alkalmazás szempontjából tekintjük át.

\section{Alkalmazási területek - a piac- és vállalatelmélet rövid áttekintése}

A piac- és vállalatelmélet, ha úgy tetszik, korábban vált elismert tudományterületté, mint a mikroökonómia, hiszen az American Economics Association 1941-ben fogadta el önálló tudományágnak, valójában persze különböző formában, nagyrészt az ár- és egyensúlyelmélet keretében kifejtve, mindkét területen a használt fogalmak

\footnotetext{
${ }^{8}$ Daubert versus Merrell Dow Pharmaceuticals, 509 U.S. 579 (1993).

${ }^{9}$ A Daubert-ügyröl és a szakértők szerepéről lásd Antal-Pomázi [2015] írását.

${ }^{10}$ United States versus IBM, 69 Civ. 200 (S.D.N.Y. 1969).
} 
köre a közgazdaságtan kezdeti időszakáig nyúlik vissza (Phillips-Stevenson [1974] 324. o.). A tudományág korai történetét vizsgáló Phillips és Stevenson megfogalmazásában a piac- és vállalatelmélet (IO) a mikroökonómia alkalmazását jelenti a monopóliumok kérdésére, a vállalatok szabályozására, a kereskedelem, ennélfogva a verseny korlátozására, miközben számos más közgazdasági területet is érint a munkagazdaságtantól a gazdasági ciklusok vizsgálatán át a vállalkozások vezetéséig. A több tucat piac- és vállalatelméleti tankönyv is azt jelzi, hogy sokféle megközelítéssel és sokféle hangsúllyal tárgyalható a piacok és vállalatok elmélete és gyakorlata. A piac- és vállalatelmélet tárgyának talán legszélesebb megfogalmazása az lehetne, hogy a tökéletlen piacok müködésével foglalkozik (Cabral [2000] 3. o.).

A 19. század végének közgazdasági vitái mind Észak-Amerikában, mind Európában a nagyvállalatok kialakulása, a fokozódó iparági koncentráció, a monopóliumok, trösztök létrejötte körül folytak, hol „antitröszt” törvénykezésig jutva [Competition Act (Kanada, 1889), Sherman Act (Egyesült Államok, 1890)], hol pedig a kartellek létrejöttét támogatva (Németország és más kontinentális európai országok, lásd Motta [2007] 10. o.). Elméleti hátteret részben Alfred Marschall munkái jelentettek, de a piac- és vállalatelmélet későbbi fejlődését tekintve legalább ilyen fontos volt, hogy 1883-ban J. Bertrand újra elővette A. Cournot müveit, majd F. Y. Edgeworth révén kialakult a diskurzus az oligopóliumok problémáiról. A monopolisztikus verseny (E. Chamberlin), a tökéletlen piacok (J. Robinson), a külső és belső gazdaságosságok (A. Pigou, P. Sraffa), a monopolárazás (F. Ramsey), a határköltségen való árazás (H. Hotelling) fogalma fokozatosan beépült abba a közgazdasági ismeretanyagba, amely J. Tirole megfogalmazásában a piac- és vállalatelmélet első hullámát alkotta az 1930as évek elejétől (Tirole [1988] 1. o..). ${ }^{11}$

A J. Bain és E. Mason nevéhez köthető első hullámot - képviselőinek egyetemi hovatartozása miatt - szokás harvardi iskolának is nevezni, az általuk kialakított struktúra-magatartás-teljesítmény (SMT) modell ${ }^{12}$ több évtizedre meghatározta a piacelméletben és empirikus elemzésben használt gondolkodási keretet. ${ }^{13} \mathrm{~A}$ vizsgálat kiindulópontja nem a vállalat, hanem az iparág, ágazat lett, amelynek szerkezete alapvetően meghatározza a vállalatok döntéseit, viselkedését, és ennek eredményét látjuk a vállalatok teljesítményében. Az oksági viszonyok ebben a modellben egyirányúak voltak, a teljesítmény kevés hatással van az iparágak szerkezetére, azt az ágazatok közötti technológiai különbségek határozták meg (Phillips-Stevenson [1974] 339. o.). Ez az elméleti keret nagyszámú, a harvardi körön túlnyúló, empirikus kutatást indított el, egyben alapul szolgált alternatív elméleti megfontolások kialakulásához.

A tökéletlen piacok, a monopóliumok, oligopóliumok elemzése egyben az ágazati szabályozók, a közszolgáltatók szabályozásának a világa is. Kezdetben a közszolgáltatásokra vonatkozó koncessziók kiadása, később a szabályozó szervezetek felállítása nagyszámú empirikus anyagot és megoldandó problémát szolgáltatott a

\footnotetext{
${ }^{11}$ A közgazdasági elemzés eszköztárának versenyjogi szempontú, történeti áttekintését európai szemszögből adja Hildebrand [2009].

${ }^{12}$ A magyar szakirodalomban szokás struktúra-viselkedés-teljesítmény (SVT) modellként is említeni, és hogy az angol rövidítést is megemlítsük: structure-conduct-performance (SCP).

${ }^{13}$ Egyben mindig kapcsolatot teremtett az intézményi közgazdaságtan művelőivel.
} 
közgazdasági viták kibontakozásához. ${ }^{14}$ Az Amerikai Közgazdasági Társaság egyik alapítója (1885), első titkára, majd elnöke, R. T. Ely a korszellemnek megfelelően a természetes monopóliumok és trösztök kérdésével is foglalkozott. A monopolárazás, a határköltségen történő árazás problémájához H. Hotelling után A. Lerner és R. Coase is csatlakozott, amelynek egyik leágazása a csúcsideji árazás (M. Boiteux) kérdésének a vitája volt. A szabályozási torzulások vizsgálatakor többek között a túlkapitalizálódás (over-investment vagy over-capitalization) kérdését vizsgálták $(H$. Averch és L. Johnson). A szabályozott monopóliumok problémáinak és a versenyszabályozás kérdéseinek nevezetes találkozási pontja volt az amerikai AT\&T távközlési vállalat 1984-ben bekövetkezett szétdarabolása, amelyet a természetes monopólium létéről, meghatározásáról szóló viták kísértek. ${ }^{15}$

Az első hullám elméleti nyeresége volt J. Bain oligopolpiacokon alkalmazott belépésikorlát-elemzése, de közben fokozatosan áttevődött a hangsúly a chicagói egyetem közgazdászainak elemző munkáira, így például G. Stiglerére, aki az elsők között kísérelte meg a verseny mértékének a meghatározását az amerikai gazdaságban (Phillips-Stevenson [1974] 341. o.). A döntően a neoklasszikus árelméletből kiinduló chicagói iskola, bár alapos elméleti elemzést követelt, fontosnak tartotta az egymással versengő elméletek empirikus tesztelését is (G. Stigler, S. Peltzman). Stigler személyében mind a piac- és vállalatelmélet, mind a szabályozás-gazdaságtan művelöjét tisztelhetjük, mindkét területen jelentős érdemei vannak, döntő szerepe volt az információ közgazdasági elemzésének elindításában, a szabályozás érdekrendszerének feltárásában. A módszertani befolyáson túl a chicagói iskola egyfelől megengedőbben ítélte meg a piaci magatartást olyan kérdésekben, mint például a kiszorító árazás, másfelől pedig a harvardi szemlélethez viszonyítva, kevésbé pártolta a kormányzati beavatkozásokat (Valentiny [2018]).

Valójában az „iskolák” térben és kutatott témákban is szétszórtabbak voltak az itt vázoltnál. A struktúra-magatartás-teljesítmény modellje érvényességének megkérdőjelezésében és a hatékonysági szempontok alaposabb érvényesítésében például H. Demsetz, a Kaliforniai Egyetem (UCLA) közgazdásza játszotta a legnagyobb szerepet (Wright [2009] 6. o.), igaz, többekkel együtt a chicagói nézetrendszerhez sorolták. Az iskolák sokféleségére további példa az AT\&T keretében működő Bell Labs közgazdasági részlege (Bell Laboratories Economics Research Center), amely a Bell Journal of Economics and Management (később Rand Journal of Economics) címü lapot adta ki. A mủhely és a folyóirat körül a szabályozás kérdéseivel magas színvonalon foglalkozó közgazdasági elemző közösség alakult (többek között E. Bailey, W. Baumol, J. Panzar, W. Vickrey, O. Williamson, R. Willig), a résztvevők közül W. Baumol Panzarral és Williggel együtt a megtámadható piacok elméletét dolgozta ki (Crew-Parker [2006] 6-7. o., Arenson [1983]).

A piacelmélet - Tirole által - második hullámának nevezett időszak kezdetei az 1970-es évekre esnek. Ekkorra a struktúra-magatartás-teljesítmény elméleti keret

\footnotetext{
${ }^{14}$ A szabályozás gazdaságtanának kérdéseit és történeti fejlődését részletesen bemutatja Kiss Ferenc László írása (Kiss [2008]).

${ }^{15}$ A felmerült közgazdasági kérdéseket Berg-Tschirhart [1988] és Evans (szerk.) [1983] könyvek foglalták össze.
} 
érvényessége már megkérdőjeleződött, de az empirikus munkák nem szolgáltattak kellö alapot egy új elméleti háttér kialakulásához. Azok, akik iskolák, egyetemek körül kialakult mühelyekhez kötik a közgazdasági elméletek változásait, ezt a máig nyúló korszakot posztchicagóinak nevezik. ${ }^{16} \mathrm{~A}$ döntő változást a játékelméleti modellek megjelenése hozta. R. Selten már a hatvanas években foglalkozott olyan feltevésekkel, amelyekkel a piacra lépéstől való elrettentést lehetett a későbbiekben modellezni. Ezeket továbbfejlesztve a chicagói iskolának a kiszorító árazás irracionális voltáról alkotott álláspontja fokozatosan megdőlt. P. Milgrom és J. Roberts a kiszorító árazás elvi lehetőségét bizonyította be, D. M. Kreps és R. Wilson információs aszimmetria mellett vizsgálta a kiszorítás lehetőségét, D. Fudenberg és J. Tirole a félrevezető szándékú piaci jelzések szerepét járta körül a kiszorításban, J. J. Laffont és J. Tirole pedig különböző árszabályozási típusok mellett gondolta végig a kiszorító árazás valószínűségét. ${ }^{17}$

Többen úgy vélik, hogy a piac- és vállalatelmélet a játékelmélettel egy olyan közös nyelvet talált, amely azon túl, hogy sokféle, az előbbiben felvetett probléma elemzésére alkalmas, megkönnyíti a különböző témákkal foglalkozók közötti kapcsolatot. További előnye, hogy a korábbinál szigorúbb tárgyalási módot feltételez, amelyben a modellek eredményei is könnyebben értelmezhetők. Ugyanezek a tényezők viszont azzal a hátránnyal járnak, hogy elhanyagolják az ebbe a gondolkodási keretbe nehezen illeszkedő vizsgálatokat, és leszükül a tényegesen végzett elemzések köre (BagwellWolinsky [2002] 1883-1884. o.). A modellek gyors elterjedése miatt voltak, akik a játékelméleti modellek túlburjánzásától tartottak (Peltzman [1991]).

A struktúra-magatartás-teljesítmény elemzési keretben az ágazat volt a középpontban, és ágazatközi összehasonlítások révén igyekeztek értelmezni a piaci struktúra és a teljesítmény közötti kapcsolatot, amelynek során egyre világosabbá vált az endogenitás problémája, hogy az oksági viszonyokat nem sikerült megnyugtatóan tisztázni. A vizsgálat középpontja ezért módosult, a vállalat viselkedése került elötérbe: az új elemzések - az ágazatok különbözőségét és a részletek fontosságát hangsúlyozva - az ágazatok intézményi sajátosságának figyelembevételével kezdődtek. Az újfajta szemléletmódot T. F. Bresnahan „új empirikus IO”-nak (új empirikus piac- és vállalatelméletnek) nevezte (Bresnahan [1989] 1012. o.). A változás fó eredménye, hogy sok területen létrejött az empirikus módszertan. Mélyebb, de szük területre vonatkozó elemzések születtek, az általánosításra kevesebb lehetőség nyílt, azok, akik próbálkoztak vele, inkább kvalitatív megállapításokat tettek (Einav-Levin [2010] 147. o.).

A továbbiakban Einav és Levin cikke alapján bemutatunk néhány lényeges eredményt. Az egyik fontos terület a tökéletlen versenyzői piacon használható keresletbecslési módszerek kialakítása volt, amelyeket később nem piaci környezetben is fel lehetett használni. A keresletbecslésben alkalmazott termékszegmentálás vagy az instrumentális változók bevezetése az összefonódások elemzésében, a fúziók

\footnotetext{
${ }^{16}$ Különösen éles a chicagói korszakkal való szembeállítás, ha az IO versenyszabályozásban való szerepét elemzik. A chicagói korszakot konzervatívnak minősítve kiemelik, hogy a harvardi és chicagói szellemmel szemben a posztchicagói időszak kevésbé ideologikus (Pitofsky [2008]).

${ }^{17}$ A játékelméleti modelleknek a kiszorító árazás megítélését befolyásoló hatásáról lásd Valentiny [2004] 30-33. o.
} 
szimulációjában vált nagy jelentőségű eszközzé, amelyet más területeken (oktatás, egészségügy, környezetvédelem) is felhasználnak. Ezek a modellek nem mindig találják meg a választ az árak és a mennyiségek szimultán alakulásának meggyőző kezelésére (identifikációs probléma), az oksági viszonyok itt sem mindig világosak, sokszor a publikációk nem közlik a modellvizsgálat diagnosztikáit. ${ }^{18} \mathrm{~A}$ korábbinál sokkal részletesebb vállalati adatok mennyisége és elérhetősége az utóbbi időkben változott, ami a vizsgálati módszerek megbízhatóságának változásában is követhető. ${ }^{19}$

Ahhoz, hogy a piaci erő és az árverseny kérdésében állást lehessen foglalni, a keresletbecslést követően a kínálati oldal viszonyait kell elemezni. A kínálat vizsgálatánál a költségek meghatározása a legnehezebb feladat, hiszen ilyen adatok nem mindig állnak rendelkezésre, illetve félrevezetők lehetnek. Megoldás lehet a megfigyelt árakból profitmaximalizálást feltételezve következtetni a költségekre. A korszerủ elemzési módszerek kombinálják a közvetlen és közvetett költségbecslést (Einav-Levin [2010] 151. o.). Az árversenyhez hasonló helyzetet elemeznek az aukciós piacokon: a licitáló cégek esetében a magasabb nyerési esély és a nyerés esetén elérhető magasabb profit közötti átváltás hasonló jellegü, mint a hagyományos termékpiaci árazásnál a nagyobb értékesítési volumen és a magasabb árrés közötti választás.

$\mathrm{Az}$ aukciós piacok elemzése az aszimmetrikus információs helyzetek egész tárházát kínálja, ezért gyakori vizsgálati területté vált. A kérdés legtöbbször a fuzionáló vállalatok tendereztetési szokásainak megváltozása vagy a közjavak (például rádiófrekvenciák) tendereztetése kapcsán merül fel. Az eddigi vizsgálatok azt mutatják, hogy a piaci részesedések nem mindig jó mérőszámai a verseny erősségének, az aukciós piacokon például egy kisvállalat jelenléte sokszor fontos hatást gyakorol a piaci kimenetre. Az aukciók vizsgálatával az is bemutatható, hogy a vállalatok mennyire „közeli” versenytársai egymásnak. A szabályozási gyakorlatban is fontos szerepet játszik az aukciós piacok vizsgálata, így például a kaliforniai árampiacon ki lehetett mutatni a piaci erővel való visszaélést. ${ }^{20}$

Az új empirikus piac- és vállalatelmélet szakirodalmának egyik próbálkozása a termékek és ágazatok életciklusának, az ágazatok dinamikájának a korábbinál alaposabb figyelembevétele. Az egyik kutatási irány az ágazatok között keresi a túlélés és a növekedés tényezőit, és fontos megállapítása, hogy a viszonylag szűk ágazatok esetén is nagy a kínálati oldal heterogenitása. Ezek az empirikus eredmények a nemzetközi kereskedelem új elméleti modelljeinek kialakulását segítették. A másik irányban, az ágazaton belüli dinamikus egyensúlyi vizsgálatokban bebizonyosodott, hogy vannak esetek, amikor a határköltségek alatti árazás felgyorsíthatja a termékek bevezetését, ezzel a bevezetés tanulási folyamatának lerövidítését, ami költségcsökkenéshez vezet (Einav-Levin [2010] 156. o.).

Einav és Levin a legtöbb eddig elért módszertani eredményt az adatok hiányára vezeti vissza. Tirole [2015] is ezt emeli ki, amikor az alkalmazás oldaláról a piac- és

${ }^{18}$ A modellek részletesebb kifejtését lásd Bishop-Walker [2011] 760-767. o. Általában a modellszámítások során közölt adatok megbízhatóságáról, a számítások megismételhetőségéről lásd Chang- Li [2015].

${ }^{19}$ A vonalkódos szkenneradatok felhasználásával készült fúzióelemzés példájára lásd Lörincz [2010].

${ }^{20}$ Az árampiacokon használt (egyensúlyi) modellekről lásd Paizs [2015], a tendereztetés vizsgálatáról Csorba [2008], [2015]. 
vállalatelmélet legfontosabb állomásait párhuzamba hozza az információs aszimmetria leküzdésével. A helyzet két irányból is változónak tünik, egyrészt egyre több és nagyobb adatbázishoz lehet hozzáférni, amelyek használatát a piaci szereplők is egyre inkább támogatják, másrészt a kísérleti közgazdaságtan olyan mérési stratégiákat helyez előtérbe, amelyek a korábbi modellek korlátait megkerülhetik. A piac- és vállalatelmélet jelenlegi helyzetében viszont elképzelhető az inga visszalendülése: az egyes piacok, ágazatok müködéséről egyre többet tudunk, ez a tudás azonban sporadikus, hiányzik a szintetizáló elmélet.

\section{A piac- és vállalatelmélet szerepe a jogalkalmazásban ${ }^{21}$}

Az ágazati és versenyszabályozás a piacok elemzésével kezdődik, nehéz lenne olyan területet találni a piacelméleten belül, amelynek ne lenne vagy ne lehetne alkalmazása a szabályozás területén. Elsősorban a második hullám - nevezzük akár modern, akár posztchicagói, új empirikus piacelméletnek - hatását próbáljuk a következőkben összegezni. Többnyire kér írás, Budzinski [2011] és Schinkel [2008] gondolatmenetét követve olyan fontosabb ügyeket és elemzési eszköztárakat veszünk sorra, amelyek a piacelmélet és a jogalkalmazás szoros kapcsolatára jellemzők. Mérföldkőnek tekinthető a kartellek vizsgálatakor, hogy a játékelmélet (fogolydilemma) segítségével sikerült meghatározni azokat a kartellt stabilizáló tényezőket, amelyek lehetővé teszik egyrészt az összejátszásra inkább alkalmas piactípusok elözetes szűrését, másrészt az engedékenységi politika alkalmazását. A fúzióknál jelentős lépésnek számított, hogy heterogén termékek esetében az egyoldalú hatások elemzésében egyidejüleg lehetett elemezni a hatékonyságjavulás tényezöit és a piaci erő nélküli helyzetekben kialakuló összejátszás lehetőségét (Motta [2007] 261-283. o.). A különböző üzleti stratégiák elemzésében a jóléti hatások következetes számbavétele hozzájárult a versenyhatások korábbinál differenciáltabb értékeléséhez. Az árdiszkrimináció megítélésében például csökkentek a versenyaggályok, a versenytárs költségeinek növelésére irányuló stratégia esetében viszont a figyelem a versenykorlátozó hatásokra terelődött.

Azokban az esetekben, ahol elegendő adat állt rendelkezésre, meggyőző elemzések készülhettek. Megfelelö adatokkal az ökonometriai elemzések mind az ex post, mind az ex ante vizsgálatokban hatásosnak bizonyultak. A kartellek, az összejátszás ex post felderítésén túl a fúziók esetében is kimutatható volt, hogy a fuzionálni kívánó vállalatok milyen versenynyomást gyakoroltak egymásra a tervezett fúzió elött. Ilyen sikeres ügynek számított az Egyesült Államokban a Staples/Office Depot ügy, ${ }^{22}$ amelyben az ökonometriai vizsgálat kimutatta, hogy a fúziós terv elött a vállalatok erős versenynyomást gyakoroltak egymásra. Ez a versenynyomás megszünt

\footnotetext{
${ }^{21}$ A hazai szakirodalom az utóbbi időben szerencsés módon bővült ebben a tárgykörben, többek között a Verseny és szabályozás évkönyvek köteteiben találhatók erre vonatkozó írások. A hazai szakirodalomról alapos áttekintést nyújt Csorba Gergely tanulmánya (Csorba [2013]).

${ }^{22}$ FTC versus Staples, Inc. (1997), 970 F. Supp. 1066 (DDC). Az ügy részletes elemzését lásd WerdenFroeb [2008] 87-88. o.
} 
volna a fúzióval, ennek alapján, az ökonometriai elemzés eredményeire hivatkozva tiltották meg 1997-ben az összeolvadást. ${ }^{23}$ Ezek az elemzési eszközök a versenyzői szegély létére és az arra gyakorolt hatás kimutatására is alkalmasak, így a fúziók ex ante elemzésében, a kiszorítás lehetőségének vizsgálatában is hasznosnak. Az adatbőség azonban némi torzítást is vihet a kutatási paletta, a vizsgált ágazatok meghatározásába, mivel elsősorban csak az elemezhető piacok kerülnek a vizsgálatok középpontjába (Budzinski [2011] 115. o.).

A piacelemzés modelljei árakból és forgalmi adatokból indulnak ki, ezeket is többnyire rövid távon elemzik, így kimaradnak egyrészt a másfajta rövid távú hatások, másrészt a hosszú távú dinamikus hatások, mint például az innováció. Az ár-és forgalmi adatokon túli tényezők kihagyása nemcsak elméletileg okoz problémát, hanem egyes ügyek megítélésében is tévútra vezethet. Míg előbb egy fúzió elutasításának közgazdasági megalapozottság szempontjából pozitív esetét említettük, addig a 2003-as részleges Nestlé/Dreyer fúzió ${ }^{24}$ (prémiumkategóriás jégkrémek) a kevéssé megalapozottak között szerepel. Elemzésében a Federal Trade Commission csak az árhatásokat vette figyelembe, az egyes márkák népszerüsítésére tett erőfeszítéseket nem, amelyek pedig a fúzió létjogosultságát támogatták volna. Tenn és szerzőtársai [2010] modellje nemcsak azt mutatta be, hogy a promóció figyelmen kívül hagyása hamis következtetésekre vezethet, hanem azt is, hogy miként lehet egyidejüleg figyelembe venni az ár és a promóció hatásait is. A nem ár jellegü hatásokat figyelembe vevő modellek száma ugyan nő, de az alkalmazhatóság határát hamar elérhetik, mert a tényezők számát növelve egyre több, egymással kölcsönhatásban lévő tényezővel kellene dolgozni.

A közgazdasági elemzési eszközök, modellek használata önmagában nem garancia a jó szabályozói döntésekre. A nagyobb versenyhatósági vizsgálatokban, bírósági eljárásokban egymással versengő, magas színvonalú, szakértők által készített elemzések alapján kell dönteni. A Microsoft-perben készült elemzések a többnyire versenyellenestől a teljesen versenyzőiig minősítették a Microsoft magatartását (Evans és szerzőtársai [2000]). A modellek körüli viták természetesen nemcsak a tárgyalóteremben zajlottak, hanem azt megelőzően és azt követően az akadémiai berkekben is, a Microsoft-perhez hasonlóan a GE/Honeywell- ${ }^{25}$ és a Volvo/Scania-ügyek ${ }^{26}$ is megosztották a szakmai közvéleményt (Bishop-Walker [2011] 659. o.). Mivel nincsen „a" jó modell, ${ }^{27}$ és a döntéshozók felkészültsége sem elegendő a választáshoz, ezért többen az intézményi feltételek

${ }^{23}$ A piaci helyzet alapos megváltozásával érvelve a cégek 2015 februárjában ismét bejelentették öszszeolvadási szándékukat, amelyet a Federal Trade Commission (FTC) továbbra is versenykorlátozónak tartott és 2015 decemberében perre vitte az ügyet. A bíróság állásfoglalásának ismeretében a két cég 2016 májusában elállt a fúziótól (https://www.ftc.gov/enforcement/cases-proceedings/1510065/ftc-vstaplesoffice-depot).

${ }^{24}$ FTC File No. 021-0174.

${ }^{25}$ Case T-209/01, Honeywell Int'l Inc. versus Commission, 2006 OJ C 48/26. Az Egyesült Államokban és az Európai Unióban zajló ügyet részletesen elemzi Grant-Neven [2005], az Európai Unióban folytatottat Motta [2007] 406-419. o.

${ }^{26}$ Volvo/Scania Commission decision, 2001/403/EC [2001] OJ L 143/74.

${ }^{27}$ Minden modell a vizsgált kérdés számos összetevőjétől kénytelen elvonatkoztatni. Budzinski [2011] ezzel kapcsolatban Joan Robinsont idézi: „Az a modell, amely a valóság teljes sokszínűségét képes figyelembe venni, nem több, mint egy 1:1 léptékű térkép.” (119. o.) 
megváltoztatását, a bizonyítási teher újraelosztását, a szakértés standardjának kialakítását, a bíró által kirendelt szakértő alkalmazását stb. javasolják. ${ }^{28}$

Kétségtelen, hogy a közgazdasági elemzések versenyjogi eljárásokban növekvő szerepével, ${ }^{29}$ a mérlegelésre kerülő ügyek számának emelkedésével a korábbinál nagyobb figyelmet kapott a termelési hatékonyság kérdése az eljárásokban. Az addig kizárólag versenyellenesnek tartott magatartásról is ki lehetett mutatni hatékonysági előnyöket. Ezt a folyamatot a versenyszabályozás gyengüléseként is lehetne értelmezni, de helyesebb inkább az ügyek közötti alaposabb szelekcióról beszélni. A chicagói iskola megengedőbb szemléletével szemben a piacelmélet új vonulata vertikális ügyekben, a domináns vállalatok viselkedésében, kizárólagossági megállapodásokban, a kiszorítás lehetőségében több körülményt ítélt versenyellenesnek, mint a korábbi felfogás. Ugyanakkor a nem kellően megalapozott vagy nem eléggé meggyőzően bemutatott közgazdasági bizonyítékok szándékolatlanul, de gyengíthetik a versenyszabályozás hitelét. Budzinski [2011] négy olyan nagyobb ügyet említ, ahol a tiltást javasló közgazdasági elemzések ellenére engedélyezték a fúziókat. Az évekkel később végzett ex post vizsgálatok megerősítették a fúziók versenycsökkentő hatását, az Oracle/PeopleSoftügyet az amerikai hatóságok mellett az Európai Bizottság ${ }^{30}$ is tárgyalta (BudzinskiChristiansen [2007], Bishop-Walker [2011] 661. o.).

A modern piacelemzések olyan, korábban ismeretlen problémákra is rávilágítottak, mint a domináns vállalatok nélküli piacokon bekövetkezö fúziók lehetséges negatív jóléti hatásai vagy egyes árengedmény típusok versenykorlátozó jellege (Budzinski [2011] 122. o.). Az új piaci problémák jelentkezése és elemzése ugyanakkor visszahatott a piacelemzés fejlődésére is. A szoftverpiacok vizsgálata a hálózatgazdaságtant gazdagította, és innovatív gondolatok születtek a monopolizáció esélyeiről (Microsoft). Az erősen szabályozott hitelkártyapiacon a korábbi versenyszabályozási vizsgálati módszerek alkalmatlannak bizonyultak, a piac problémáit csak a kétoldalú piacok elméletének kialakulásával lehetett megmagyarázni és megoldani (Visa/Mastercard-ügy, ${ }^{31}$ Tirole [2011]). ${ }^{32}$

A piacelemzések korábbi időszakát és a várható változásokat elemző írásában Borenstein úgy látja, hogy az elemzések mélységének növekedése helyett a piacelemzési eszköztár minél szélesebb körü, interdiszciplináris alkalmazásának időszaka jött el (Borenstein [2016]). Jól lehet érzékeltetni ezt a változást az energiapiacok példáján.

\footnotetext{
${ }^{28}$ A semleges szakértő bíró általi kiválasztásának lehetséges eljárását elemzi Antal-Pomázi [2015].

${ }^{29}$ Az ágazati szabályozásban a közgazdasági elemzés szükségszerüen folyamatosan jelen volt, de a különböző ágazatok piacnyitását követően a megválaszolandó kérdések köre és az elemzés eszköztára gyors ütemben bővülni kezdett (Kiss [2008]). Az ágazati szabályozás feltételei között nehezen megoldható problémákat gyakran a versenyszabályozás keretében rendezték. Ilyen példa a mobilszolgáltatók végződtetési díjával összefüggő vita. A brit versenyhatóság egy másik, viszonyításként szolgáló (benchmark) modell alapján döntött úgy, hogy ez a nagykereskedelmi szolgáltatási elem is árszabályozás alá kerüljön. A döntést követően az Európai Unió egészében megindult a végződtetési díjak csökkentésének folyamata (Armstrong-Wright [2009]).

${ }^{30}$ COMP/M.3216 Oracle/PeopleSoft (2004).

${ }^{31}$ In re Visa Check/Master Money Antitrust Litigation, Master File No. CV-96-5238 (E.D.N.Y.).

${ }^{32}$ Többek között a Visa/Mastercard-ügy is jelezte, hogy a viselkedés-gazdaságtan egyre nagyobb szerepet játszik a hatósági eljárásokban (Bailey [2015]), a pénzügyi piacokkal összefüggő átfogó értékelését lásd Vincze [2012].
} 
Ezek a piacok ideálisnak bizonyultak a piacelemzés hagyományos eszköztára mellett, hiszen nagyjából homogén termékekről volt szó, kevés piaci szereplővel, a cégek elég nagyok voltak ahhoz, hogy a stratégiai viselkedést tanulmányozni lehessen, ehhez a Cournot-Nash-féle egyensúlyi modellek megfelelőnek bizonyultak. Azonban éppen az energiapiacokon alakultak ki olyan helyzetek (például a 2000-2001-es kaliforniai villamosenergia-válság), amelyeket a hagyományos piacelemzési eszköztárral nehezen lehetett értelmezni. Egyre több írás foglalkozott a fogyasztók viselkedésének (PriceZhu [2016]), majd a szabályozók viselkedésének gazdaságtani kérdéseivel (CooperKovacic [2012]), amelyek kiegészíthetők a cégek magatartásának az eddiginél remélhetően komplexebb elemzését lehetővé tevő viselkedési gazdaságtannal.

A modern piacelemzésekről az eddigiek alapján elmondható, hogy az összejátszások, kartellek feltárásában és szürésében, az engedékenységi politika kialakításában jelentős volt a szerepük - a fúziókontrollban azonban, ahol a szimulációk során elöretekintő állításokat kell megfogalmazni, már több probléma merült fel. Az egyoldalú hatások versenyjogi aggályainak vizsgálatában a modern piacelemzés jelentős segítséget nyújtott, problémát jelentett azonban, hogy nagyobb hangsúlyt kaptak egyes ritkább esettípusok (például a kiszorító árazás), és kisebbet a gyakoribb, egyben sokféle esettípusok (mint a különféle engedmények kérdései). Laurence Idot szerint - feltehetően az adathiány és a mérhetőség problémái miatt - éppen a leggyakoribb üzleti fogások maradnak kívül az empirikus vizsgálatok és a piacelmélet érdeklődési körén (Idot [2011] 140. o.).

A piacelméletre, a közgazdasági elemzésekre nemcsak a bírósági eljárások során, hanem a vizsgált ügyek minden szakaszában szükség van. A versenyszabályozás intézményrendszere az Európai Unióban és az Egyesült Államokban különbözik. Az utóbbiban a versenyhatóságok a bíróságokon indítanak eljárást, a döntést a bíróságok hozzák. Az Európai Unióban a hatóságok hoznak döntéseket, amelyeket a bíróságokon lehet megtámadni. Az intézményrendszerbeli különbségek ellenére a piacelemzés megállapításait a teljes folyamatban - az ügyek felderítése, kivizsgálása, az ítélet-/döntéshozatal és a hozzá tartozó kötelezettségvállalások meghatározása mindkét jogrendszer felhasználja.

Az ügyek felderitésében, a versenykorlátozó magatartás gyanújának felmerülésében fontos szerepe lehet a versenyhatóságoktól függetlenül folyó közgazdasági elemzéseknek. A korábbi példákat megtoldva, megemlíthetjük azt a vizsgálatot, amellyel az árakat összehasonlító hirdetések összejátszásra gyanút adó voltát tárták fel, vagy a tőzsdei forgalomban használt mértékegységeken alapuló összejátszást állapították meg (Schinkel [2008] 6-7. o.). A felderítésnek a hatóságok által használt gyakori közgazdasági eszköze a piacok specializált részlegek által végzett rendszeres szürése. Ebben az esetben a szokatlan piaci viselkedések - például az értékesítési feltételek hirtelen megváltozása, áreltérések csökkenése, együttes és egymással korreláló kapacitásbövítések, egyes aukciós magatartások - adhatnak okot mélyebb vizsgálatra. Az információtechnológia fejlődésével lehetővé vált egyes folyamatok valós idejü követése is. A szürés másik típusa, amikor a piacok szerkezeti jegyei alapján keresik a tipikus összejátszási és kartell-lehetőségeket, ehhez a korábbi kartellügyek utólagos, részletes piacelemzése jelentős segítséget nyújt (Ghosal [2008]). 
Azok az elemzések és információk, amelyekkel a versenyhatóságok a verseny torzulását észlelhetik, természetesen a torzításban érdekelt vagy az azt elkerülni igyekvő vállalatokat is érdeklik. A vállalatok belső ellenőrzési rendszerét közgazdasági és kockázatelemző szoftverek segítik, amelyek kétes kimenetü esetekben a kialakult helyzet feltárását, az engedékenységi politika felhasználását javasolhatják, vagy segíthetik a szabályok, szabályozások teljesíthetőségét (Spagnolo [2005]).

Ha egy ügyben már felmerült a versenykorlátozó magatartás gyanúja, a következő szakaszban a közgazdasági szempontok a bizonyítékok körének meghatározásában játszanak szerepet. A dokumentumok, bizonyítékok beszerzését követően a vizsgálat elökészítésekor az eset közgazdasági logikájának a feltárása a cél, ekkor kerülnek elő a piacelmélet ismert modelljei. A fúziók esetében már a különböző piacszerkezet mellett értelmezhető szimulációs szoftvercsaládokat lehet használni, itt ezeknek a konkrét ügyhöz való illesztése a megoldandó feladat. Azokban az esetekben, amikor az ügyeket az amerikai és az európai hatóságok is vizsgálják, a hatóságok között gyakran mutatkoznak eltérések az elemzési eszközökben (és a végeredményben is) (Grant-Neven [2005], Valentiny [2004], [2011]). ${ }^{33}$ Általános vélekedés azonban, hogy az amerikai és az európai megközelítések az elmúlt két évtizedben sok szempontból közeledtek, ami a fúziókontrollban inkább, a piaci erő és a vertikális korlátozások megítélésében kevésbé érzékelhető (Vickers [2007]). ${ }^{34}$

A gyanús és a bejelentett esetek nagy száma és a hatóságok ehhez képest szükös erőforrásai miatt a részletes vizsgálatra kerülö ügyek kiválogatására, a kiválogatott ügyekből a részletes, érdemi vizsgálatra szánt ügyek körének meghatározására teszteket, szürőket alkotnak, szabályokat fektetnek le. A bíróságok maguk is keresik azokat a szempontokat, közgazdasági eszközöket, amelyek az ügyek gyorsabb elbírálását, hatékony müködésüket elősegítik. Ilyen szerepet töltenek be a küszöbértékek, amelyek alatt (vagy felett) az ügy további vizsgálatára nincs szükség, és ezt a funkciót tölti be a vizsgálatok több (általában két) szakaszra bontása, amikor további szelekciós lehetőséget építenek be az eljárásokba. Ezeket a szabályokat irányelvekben, útmutatásokban fogalmazzák meg a hatóságok, illetve a bírói gyakorlat alakítja ki.

Az Egyesült Államok bírósági gyakorlatában kialakult per se szabály részben ezt a funkciót kívánta betölteni. A Sherman Act 1890-es elfogadása után, 1911-ben két bírósági ítéletben fogalmazták meg alkalmazásának eljárási elveit. A per se szabály szerint bizonyos üzleti magatartásokat a magatartás egyéb körülményeinek mérlegelése nélkül, önmagában tiltani lehetett, egyéb esetekben az ügy érdemben mérlegelésre kerülhetett (rule of reason) (Gavil [2010], Török [2011], Sokol [2014]). Azt, hogy melyik tevékenységre érvényes a per se tiltás szabálya, bírósági ítéletek mondták ki.

\footnotetext{
${ }^{33}$ Közgazdasági és jogi kérdések megítélésében gyakran a két amerikai hatóság (Federal Trade Commission, Department of Justice Antritust Division) között is éles ellentétek lehetnek (ValentinyKiss [2009] 1007-1008. o.).

${ }^{34}$ Az elmúlt évtizedben a Review of Industrial Organization folyóirat minden évben egy teljes számot szentel az Egyesült Államokban és az Európai Unióban a verseny- és ágazati hatóságok által alkalmazott közgazdasági elemzési módszerek ismertetésének. Az első öt év alapos összefoglalását nyújtja Muraközy [2015].
} 
Így például 2007-ben a Leegin-ügyben ${ }^{35}$ szűnt meg a minimális viszonteladói ár meghatározásának per se tiltása, az ilyen jellegü versenykorlátozás gyanúját ettől kezdve mérlegelés után lehet csak eldönteni. A Leegin-ügyben az erre az ügytípusra vonatkozó, 1911 óta érvényben lévő szabály dőlt meg 96 év után.

A per se tiltás szabályának sok előnye volt: világos választóvonalat húzott a tiltott és a megengedett magatartás között, kiszámíthatósága jól orientált az üzleti döntésekben, perek esetén egyszerű volt az eljárás, korlátozta a figyelembe veendö bizonyítékok körét, a bizonyításra könnyen, gyorsan, kisebb költséggel kerülhetett sor (Cavanagh [2013] 8-9. o.). A közgazdasági megfontolások térnyerésének következtében azonban az 1970-es évek végétől az ügyek egyre nagyobb részében olyan döntések születtek, amelyek a korábbi per se tiltás helyett a mérlegelést tették szabállyá (árukapcsolás, területi kizárólagosságot kimondó szerződések, viszonteladói ár stb.). Mára az Egyesült Államokban a per se tiltások körében csak a kőkemény (árrögzítő, piacfelosztó) kartellek maradtak (White [2010] 39-41. o., Gavil [2010] 838-840. o., Markham [2012] 593. o.).

A világosan követhető tiltások helyében támadt ürt a mérlegelést segítő szempontokkal kezdték kitölteni. Az addigi eljárásokban már részlegesen alkalmazott, többlépcsős szűrővel (piaci erő jelenléte, a profit és a versenykorlátozás közötti logikai kapcsolat) kívánták az ügyek súlyát, a versenykorlátozás nagyságrendjét megítélni (Easterbrook [1984]). A hatóságok (FTC, DoJ) a mérlegelésre váró (rule of reason) ügyek körén belül megfogalmazták a ránézésre, „természeténél fogva gyanús” esetek kategóriáját, ezeknél részletes piacelemzés nélkül is perre vihetőnek ítélték az ügyet (FTC-DoJ [2000] 4. o.). A szürők beépítésének igényéhez hamarosan tudományos háttér is társult, a döntéselmélet alapján az információhoz jutás, valamint a költségek és hasznok számbavételével próbálták modellezni az egyes ügyeknél alkalmazható megoldásokat (Beckner-Salop [1999]). A szabályozási folyamat egészét tekintve a beépített szűrök léte a folyamatot gyorsítja, kiszámíthatóbbá teszi, de ennek ára van, a vállalati magatartás megítélésénél elkövetett hiba nagyobb lehet. Ezzel szemben a kevésbé kiszámítható, teljes eljárások kisebb tévesztési arányához a folyamat magasabb költsége társul (Baker-Bresnahan [2008] 25-26. o.).

Érdemes röviden áttekinteni az egyik első és legelterjedtebben használt szürő, a kiszorító árazásnál használt Areeda-Turner-teszt alkalmazásának változásait (Areeda-Turner [1975]). ${ }^{36} \mathrm{~A}$ teszt egyszerü formában próbálja eldönteni az árazási magatartás versenykorlátozó jellegét. Eszerint a rövid távú határköltség alatti árazás gazdaságilag nem hatékony árat jelent a monopolista piaci szereplő számára, ezért kiszorító árazásnak tekinthető. Ha az ár a határköltség alatt van, de magasabb az átlagos összköltségnél, és a hasonló hatékonysággal dolgozó versenytársat nem zárja ki a piacról, akkor nem tekinthetö kiszorítónak. Mivel a határköltségekre vonatkozó adatokhoz általában nem lehet hozzáférni, ezért helyettük az átlagos változó költségre vonatkozó adatokat javasolták. Végső formában a teszt úgy szólt, hogy ha az ár

\footnotetext{
${ }^{35}$ Leegin Creative Leather Products, Inc. versus PSKS, Inc., 551 U.S. 877 (2007).

${ }^{36}$ A kiszorító árazásnál alkalmazott amerikai és az attól eltérő európai tapasztalatok részletesebb elemzését lásd Valentiny [2004], Giocoli [2014].
} 
az átlagos változó költségek szintjén vagy a felett van, akkor nincs szó kiszorító árazásról, ha az alatt, akkor igen.

Az Areeda-Turner-szabály a cikk megjelenését követően nagy vitát váltott ki (Vernon és szerzőtársai [1995] 283-290. o., Bolton és szerzőtársai [2000] 2250- 2255. o.). Egyrészt szívesen alkalmazták a bírósági gyakorlatban, aminek eredményeként a kiszorító árazás tényállásának megállapítása radikálisan csökkent, de kételyeket támasztott még a jogalkalmazók körében is, mert a szabály túlzottan megengedőnek tűnt. Másrészt a közgazdasági érvényességét is vitatni kezdték, és hamarosan alternatív javaslatok születtek.

A közgazdasági elemzések körének bővítését javasló írások a hangsúlyt a kiszorító árazás mint stratégiai magatartás vizsgálatára helyezték. A költség- és piaciszerkezetadatokat kiegészítették a vállalat törekvéseinek dokumentumaival. Az erre tett kísérlet legátfogóbb példája a Joskow-Klevorick-féle szabály, amelyben két szakaszra javasolták szétválasztani a kiszorító árazásban indult vizsgálatot (Joskow-Klevorick [1979]). Az első szakaszban a piaci szerkezet vizsgálata alapján kellett eldönteni, hogy egyáltalán lehet-e szó a kiszorító árazás sikeres végigviteléről. Például nagyon alacsony belépési korlátok mellett az ügyet már ebben a szakaszban ejteni lehetett. Ha ezen az első szakaszon túljutott az eljárás, akkor a második szakaszban került sor a költségalapú vizsgálatokra és az árak viselkedésének tanulmányozására.

A kiszorító árazással összefüggő peres ügyek vizsgálata azt mutatta, hogy az Areeda-Turner-cikk megjelenése előtti időszakban a panaszosok az esetek 77 százalékában nyertek, ugyanakkor a cikk megjelenése utáni hét évben ez az arány 8 százalékra csökkent. Majd a rá következő tíz évben, amikor már az Areeda-Turner-szabály kiegészített változatait használták a jogi eljárásokban, a panaszosok sikerszázaléka 17 százalékra emelkedett, ami a gyakorlatban feltehetően ennél is magasabb volt, mert a peren kívüli egyezségeket nem számították bele (Bolton és szerzőtársai [2000] 2254. o.). Az 1990-es évek elejére az a benyomás alakulhatott ki, hogy a kiszorító árazással szembeni jogi védelem többé-kevésbé egyensúlyba került. A panaszosoknak továbbra sem volt könnyü pert nyerniük, viszont a kiszorító árazás kirívó esetei nem maradtak megtorlatlanok. Ezt a kiegyensúlyozott helyzetet kérdőjelezte meg a Brooke-ügyben ${ }^{37}$ hozott, 1993-as legfelsőbb bírósági döntés, amely az elveszett profit visszanyerésének vizsgálatát állította a középpontba (uo. 2255. o.).

A Brooke-ügyben hozott döntés utáni hat évben (1993-1999 között) kiszorító árazással jelentkező panaszos nem nyert a bíróságokon, ennek ellenére a bírósági gyakorlatban kezdték figyelembe venni a modernebb, játékelméleti megközelítés megfontolásait és ajánlásait. A modern közgazdasági megközelítések használatát és a viszszanyerés kérdésének ebbe a körbe való beillesztését szolgálta a Bolton és szerzötársai [2000] által javasolt eljárásrend. A javaslat a meglévő szabályozást vette figyelembe, és a kiszorító árazást öt feltételhez kötötte: 1. kedvező piaci struktúra, 2. a kiszorító árazásra utaló lépéssorozat és az ezt igazoló bizonyítékok, 3. a visszanyerés lehetősége, 4. a költség alatti árazás, 5. az üzletvezetési és hatékonysági indokok hiánya. Az öt elem együttese kétfázisú vizsgálatot tesz lehetővé. Az első három elem - mint első

\footnotetext{
${ }^{37}$ Brooke Group Ltd. versus Brown Williamson Tobacco Corp., 509 U.S. 209. No. 92466.
} 
szakasz - szürőként is szolgál, amelyik ügy ezen túljutott, a részletes költségelemzések tárgyává válhat, és ekkor vizsgálja a bíróság, hogy vajon dominánsak-e a versenykorlátozó szándékok. Az első négy pontot a panaszosoknak, az utolsót a perre vitt vállalatnak kell bizonyítania (uo. 2264. o.).

$\mathrm{Az}$ Areeda-Turner-tesztet javasló írás megjelenésének 40. évfordulójára a Review of Industrial Organization folyóirat különszámban tekintette át a szabály hatását. Összegzésként megállapították, hogy a szabály alkalmazásával a stratégiai viselkedés egy lényeges szelete került ki a versenyszabályozás alól, de egyszerüsége és könnyen alkalmazhatósága miatt a bíróságok szívesen élnek vele (Hovenkamp [2015]). A kutatók számára a fö kérdés nem az árak különböző költségtípusokhoz való viszonyának alakulása volt, hanem az, hogy a domináns piaci szereplő árazása hogyan hat a belépni szándékozókra és a versenyzői szegélyre. Az empirikus elemzések alapján úgy vélték, hogy a szabály elsősorban az ügyek kezdeti, vizsgálati szakaszában használható, de abban sem szabad kötelező és a döntést befolyásoló jelleggel használni (ComanorFrech [2015]). A kétoldalú piacoknál pedig esettanulmányokban mutatták ki, hogy alkalmazása félrevezetö eredményt ad (Behringer-Filistrucchi [2015]).

A kétoldalú piacokat elemezve az elmúlt években született tesztek alkalmassága is megkérdőjeleződött. A sokféle terméket gyártó cégek horizontális fúziójánál a hagyományos módszer (piacmeghatározás, koncentrációs mérőszámok értékelése) helyett az árakra ható nettó felfelé irányuló nyomás (upward pricing pressure, UPP) vizsgálatát javasolták (Farrell-Shapiro [2010], Carlton [2011]). A szürésre használt teszt hamar bekerült a hatóságok eszköztárába, először az amerikai, majd a brit, végül az európai uniós fúziós irányelvekbe is beépült. A teszt kétoldalú piacokra való kiterjesztésének első eredményei azt mutatják, hogy a fúziók árhatása nagyobbnak mutatkozik, mint akkor, ha csak az egyik oldal szempontjából végeznék el az elemzést, és a teszt adatigénye egyes esetekben olyan mértékben növekedne, ami az elvégzését irreálissá teszi (Affeldt és szerzötársai [2013]).

A tesztek, szürök, szabályok, gyorsan bevethető eszközök kigondolása és ezek használhatóságának folyamatos felülvizsgálata a versenyügyekkel, szabályozással foglalkozó közgazdasági elemzés része. Az ezek létrehozására való ösztönzés a jogalkalmazók (hatóságok, bíróságok, ügyvédek) oldaláról erőteljesen érzékelhető, és a közgazdasági kérdések túlzott leegyszerüsítésének veszélyével járhat. Ezt enyhítheti, hogy egyre több kettős végzettségü (jogi és közgazdasági) szakember dolgozik ezen a területen, és a hatóságokon, bíróságokon is folyik közgazdasági képzés (Baye-Wright [2011], Wright-Diveley [2013], OECD [2008]).

A közgazdasági elemzések minősége a jogérvényesítés döntési, ítélkezési szakaszában is valószínüleg a nyilvánosság segítségével biztosítható leginkább. Ezzel ki lehet szűrni az ügy érdemi elbírálásától eltérítő érdekeket, meg lehet ismerni az ügyekben hozott döntések egymásra épülő logikáját, és így lehet az eljárásokban részt vevő közgazdászoknak hírnevet szerezni (vagy azt elhomályosítani). Az Egyesült Államokban a nyílt bírósági eljárások azt is követhetővé teszik, hogy melyik közgazdasági szakértő milyen típusú félnek a leggyakoribb szakértője. A közgazdasági szakértők kiválasztása, a bíróság előtti tanú szerepére való felkészítése ma már önálló jogi szakterületté vált. A szakértés is két szakaszra bomlott: vannak, akik 
inkább az ügy előkészítésében, konzulensként dolgoznak, és vannak, akik inkább a bíróság előtti tanúvallomásra alkalmasak. Az előbbiekkel az ügy olyan részletei is megvitathatók, amelyeket a bíróság előtti szakaszban a felek már nem kívánnak megtárgyalni, a bíróság előtti tanú esetén viszont a hírnév is fontos szempont. Mindazonáltal, a polarizáció ellenére, ki lehet alakítani olyan mechanizmusokat, kódexeket, amelyekkel a pártatlanságot biztosítani lehet, ebben a szakértők közötti verseny és a hírnév fontossága is segít (Posner [1999]).

Közgazdasági megfontolásokra, elemzésekre a kötelezettségvállalások, szankciók megszabásához, a károk megállapitásához is szükség van. A versenyproblémák megoldása gyakran strukturális változásokat igényel, fúzióknál egységek, termékek stb. leválasztásáról kell dönteni, más esetekben magatartási szabályokat kell meghatározni. Ezekben az esetekben a döntést segítő közgazdasági elemzések már a versenykorlátozás feltárásánál elkészülnek, ezek alapján kell olyan javaslatokat tenni, amelyek megszüntetik a versenykorlátozást, és elrettentenek a jövőbeli visszaélésektől. Egyes versenykorlátozó lépéseknek büntetőjogi következményei is lehetnek, emiatt az ösztönzőrendszerek vizsgálata, a vállalatvezetéssel összefüggő tudományok és a szervezet-gazdaságtan is szerepet kap a szankciók megtervezésében. A károk megállapításához gyakran a kár előtti állapot felmérésére is szükség van, az itt használt eszköztár a költségszámításokon túl árelemzéseket, valószínűségszámítást igényel (Schinkel [2008] 23. o.).

Ebben az alfejezetben bemutattunk néhány, a piac- és vállalatelmélet szempontjából fontos mérföldkövet, amelyek egyfelől a piacelmélet ágazat- és versenyszabályozásban betöltött növekvő szerepét illusztrálták, másfelől a szabályozás által felvetett problémáknak az empirikus és elméleti kutatásokra gyakorolt ösztönző hatását jelezték. Tárgyaltuk az adatok hiányából (vagy bőségéből) adódó problémákat, az ár- és értékesítési adatokon túli dimenziók fontosságát, a szabályozási eljárásokban gyakran egymással versengő modellek okozta problémákat, valamint azt, hogy a közgazdasági elemzési eszközök szerepének növekedésével egyre fontosabb az elvégzett elemzés minősége, mert közgazdasági bizonyítékok nem eléggé meggyőző bemutatása szándékolatlanul gyengítheti a versenyszabályozás hitelét. Ezután a szabályozás „ügymenetét” követve - a gyanús esetek kiszürése, a felderítés, a vizsgálat és a döntéshozatal egyes szakaszaiban - tekintettük végig a piacelemzési eszközök használatának problémáit. Kiemelten foglalkoztunk az eljárásokat könnyítő, gyorsító szürők, tesztek, szabályok kérdésével, amely az alkalmazott közgazdasági elemzés elkülönülő ágának tűnik. A továbbiakban azt a társadalmi közeget tekintjük át, amelyben a jog és a közgazdasági elemzés összekapcsolódik.

\section{Jogászok és közgazdászok}

A különböző jogágak közül valószínűleg a versenyjog és a hálózatos közszolgáltatásokkal összefüggő jogalkotás kapcsolódik a legszorosabban a közgazdaságtanhoz, ezen belül a piac- és vállalatelmélethez. Az ott született törvények a közgazdaságtan fogalmi kereteit használják, csak velük együtt értelmezhetők. Új, a jogalkalmazás gyakorlatában 
jól használható közgazdasági elemzési eszközök hamar bekerülhetnek a bírói gyakorlatba. Az Areeda-Turner-szabályt javasló cikk 1975-ös megjelenése utáni két évben már hat amerikai bíróság alkalmazta, és 1975-2000 között több mint száz versenyjogi döntésben hivatkoztak az írásra. O. E. Williamson szavaival, hirtelen a kiszorító árazással vádolt alperesek paradicsoma jött létre, amiből számunkra a hirtelen szó az érdekes, a dolog érdemét itt nem tárgyaljuk (idézi: Giocoli [2014] 281. o.).

Az új fogalmak elterjesztésében a nem kötelező erejü jogi eszközök (soft law irányelvek, útmutatások, állásfoglalások) is egyre nagyobb szerepet játszanak, részben, mert a korábbinál nagyobb mértékben támaszkodnak rájuk a jogalkalmazásban. Az egyik ilyen példa a piaci koncentrációs mutató használatának változása az amerikai joggyakorlatban. A fúziókról 1982-ben kiadott iránymutatás a HerfindahlHirschman-index $(\mathrm{HHI})^{38}$ használatát javasolta. A megelőző időszakban az 1968-as iránymutatás alapján a négy legnagyobb vállalat együttes részesedéséből képzett koncentrációs méröszám $\left(C_{4}\right)$ használata volt érvényben. Annak ellenére, hogy a $C_{4}$ index használhatóságát már ekkor vitatták, és javasolták a HHI bevezetését, 1970 és 1982 között mindössze hét ítéletben hivatkoztak rá. Az iránymutatás megjelenése után a HHI használata általánossá vált, ahol mindkét indexre hivatkoztak, mindenütt a HHI megbízhatóbb voltát emelték ki az ítéletekben. Ebben az iránymutatásban szerepelt a piac meghatározásához használható hipotetikus monopolista (Small but Significant and Non-transitory Increase in Price, SSNIP) teszt bevezetése is. Az iránymutatások hatása a jogalkalmazásra erősödött, míg a hetvenes évek elejétől 1982-ig az 1968-as iránymutatásra az ítéletek 10-20 százalékában, addig az új, 1982-es iránymutatás megjelenése után, 1983-ban már 50 százalékban hivatkoztak, s ez az arány az 1980-as évek végére 60 százalékra nőtt (Greene [2006] 790-791., 796., 804. o.).

Az egymást követő harvardi, chicagói, posztchicagói iskola befolyását és ezeknek a hatásoknak az Európai Unióba való beszivárgását, a jogi és közgazdasági szempontok fokozódó együttélését egy sajátos piac kialakulásaként is felfoghatjuk. Más szakmáktól eltérően, ahol a kutatók és a szakértők elkülönülnek, a közgazdászok körében gyakran a szakma élvonalához tartozó tudományos kutatók vesznek részt a peres eljárásokban, készítenek szakmai véleményt, vagy egyszerüen csak vitatják meg az egyes döntések szakmai megalapozottságát. A versenyhatóságoknál a vezető közgazdász posztjának a létrehozása is jelzi a közgazdasági szempontok elötérbe kerülését, de egyben azt is jelzi, hogy az adott közegben milyen megbecsülésnek örvend a közgazdasági szemléletmód. Az Európai Unió Versenypolitikai Főigazgatóságán a vezető közgazdász posztját kiváló, versenypolitikában jártas közgazdászok töltik be, hasonlóan az Egyesült Államokhoz, ahol már a Federal Trade Commission 1915-ös megalakulásakor létrejött ez a poszt. A legnagyobb cégek is gondoskodnak arról, hogy tanácsot és/vagy védelmet kapjanak vezető közgazdászoktól: Hal Varian 2007 óta a Google vezető közgazdásza, Preston McAfee 2007-2012 között a Yahoonál, 2014-2018 között a Microsoftnál töltött be hasonló pozíciót.

${ }^{38}$ A Herfindahl-Hirschman-index a piacon lévő vállalatok piaci részesedésének négyzetösszegét adja, szemben a $C_{4}$ mérőszámmal, amely a legnagyobb négy vállalat piaci részesedésének százalékban megadott összege. 
A közgazdasági tanácsok, elemzések fogadókészségének növekedésével a kínálat is növekedett, bár a kereslet növekedésében a kínálat minősége és használhatósága is nyilvánvaló szerepet játszott. Az európai tanácsadó piacon azonban nem a versenyszabályozás adta az első lökést az önálló közgazdasági elemző, tanácsadó részlegek elterjedéséhez, hanem az Egyesült Királyságban elindult, majd a kontinensre is átterjedő privatizációs és deregulációs hullám. Bizonyos közgazdasági elemzéseket a privatizációs lépések is megköveteltek, de a legnagyobb feladat a privatizált monopolhelyzetű közszolgáltatók szabályozásának megoldása volt. Ennek során többek között olyan innovatív árszabályozási rendszert vezettek be, amelyet a későbbiekben a legtöbb országban átvettek. ${ }^{39}$

A kiépülő ágazati szabályozások rendszere egyrészt az ágazatok szabályozásában jellemző ex ante szabályozási problémákkal került szembe, de mert a privatizáció és a dereguláció fő szempontja a versenyhelyzet megteremtése és erősítése volt, ezek az ágazatok gyorsan szembesültek a versenyszabályozás klasszikus kérdésköreivel (Valentiny [2008]). A felmerülő igényekre válaszul a nagy könyvvizsgáló cégek, befektetési bankok sorra állították fel privatizációs és szabályozási részlegeiket, és önálló közgazdasági tanácsadó cégek is alakultak. Az 1961-ben amerikai közgazdászok (I. Stelzer, P. Joskow) által alapított National Economic Research Associates (NERA) 1984-ben irodát nyitott Londonban. Az Oxera 1982-ben, a London Economics 1986-ban kezdte meg működését, a Lexecon 1991-ben. A későbbiekben újabb amerikai cégek jelentek meg a brit piacon, a LECG és a CRAI, az utóbbi 2005-ben felvásárolta a Lexecont. A 2000-es éve közepére viszonylag töredezett piac alakult ki, hasonlóságot mutatva az amerikai piaccal, három olyan nagyobb céggel, amely transzatlanti hatókörrel rendelkezett. A jogi tanácsadókhoz hasonlóan a közgazdasági tanácsadó cégek is elsősorban a vállalatok megbízásaira dolgoztak (Stelzer [1991], Neven [2006]).

A Lexecon által készített becslésekben az 1990-es évek közepén az európai bázisú cégek teljes jogi és közgazdasági tanácsadói díjazásán belül a közgazdasági tanácsadás részaránya 5 százalék körül lehetett, ez az arány egy évtizeddel később 15 százalékra nőtt, ami nagyjából megfelelt az Egyesült Államokban kialakult arányoknak. A PricewaterhouseCoopers azt állapította meg, hogy a fúziókkal és felvásárlásokkal kapcsolatos jogi tanácsadás díjazásának 20 százaléka került nem jogi tanácsadókhoz, amelyek többsége közgazdasági tanácsadó volt. A megbízások elnyerésének és áramlásának irányát nem ismerjük, de feltehetően a jogi irodák voltak a domináns partnerek. Az Európai Unió versenyhatósága által 1991-2005 között tárgyalt ügyek elemzése azt mutatta, hogy a közgazdászok inkább az új típusú, komplex és nagyméretü tranzakcióval járó ügyekbe voltak bevonva. A verseny a közgazdasági tanácsadók között a kevés, nagy volumenü ügyért folyt, szemben a jogi tanácsadással, ahol nagyszámú üggyel foglalkoztak. Neven [2006] becslése szerint 2003-ban, amikor az EU versenyigazgatóságán a vezető közgazdász melletti munkacsoportban 10 közgazdász

\footnotetext{
${ }^{39}$ A távközlésben először 1984-ben bevezetett ársapka- (price cap) szabályozást követő évben az Egyesült Államok távközlésénél 50 tagállamában még a hagyományos, megtérülési ráta (rate of return) típusú szabályozás volt érvényben. 2000-ben már 40 tagállam az ársapka szerint szabályozta távközlési cégeit (Sappington [2002]). Az ösztönző szabályozás térnyerését a megbízó-ügynök-elmélet és a játékelméleten alapuló modellvizsgálatok is segítették (Laffont-Tirole [1993], Armstrong-Sappington [2004]).
} 
dolgozott, akkor a tanácsadó cégek durván 150 közgazdászt, az FTC és a DoJ több mint 100 közgazdászt foglalkoztatott (749-752. o.).

A közgazdászok itt olyan közegben mozognak, ahol az empirikus elemzésekkel foglalkozó elemző, a jogász, a kutató, a hatóság képviselője, a bíró közösen alakít ki egy müködési területet. Az itt dolgozó közgazdászok általában a határidők és erőforrások szorításában fejtik ki tevékenységüket (Csorba [2014] 15-17. o.). Bár a közgazdaságtanról sokan úgy tartják, hogy semleges álláspontot alakít ki, valójában az intézmények nyomása lényegesen befolyásolhatja a kutatók viszonyát az eljárásokban felhasznált bizonyítékokhoz, az eredmények bemutatásához. Amíg a tudományos tevékenységben a tudományos mérce szerinti ellenőrző folyamat dominál, a jogalkalmazás területén használt közgazdasági elemző eszközöknél a felhasználói oldal befogadóképessége, az ügyek kimenetelének sikeressége válik mércévé. I. Lianos úgy fogalmaz, hogy kétféle igazság létezhet egy jogalkalmazással összefüggő kérdésben dolgozó közgazdásznál, a tudományos és az, amit a bíróság annak tekint és elfogad, mert ugyanaz az állítás egy akadémiai vitában más közegben hangzik el, mint egy perben elmondott tanúvallomásban (Lianos [2012] 30-31. o., Slottje [1999]). Ezt a helyzetet 1982-ben G. Stigler így írta le:

„A közgazdászok közvetlen szerepvállalásának jelentőségét, azt hiszem, nem szabad sem alá-, sem túlbecsülnünk. Azt gyanítom, hogy azok a közgazdászok, akik haszonélvezői (a folyóiratot is beleértve) a Bell-rendszernek [utalás az AT\&T vállalatra], valószínűleg kisebb vehemenciával bírálják ezt a rendszert, mint egyébként tennék. Ugyanígy: a szakértőnek felkért közgazdászok minden bizonnyal óvatosabban ítélik meg a gazdasági koncentráció hatásait, és körültekintőbben definiálják a piac fogalmát az egyes trösztellenes ügyekben, mint egyébként tennék.” (Stigler [1989] 209. o.)

A verseny- és ágazati szabályozás 19. század végén kezdődött korszaka a jog és a közgazdaságtan kezdetben távoli, majd egyre jobban egymásra utalt kapcsolatát alakította ki. Az 1960-as évekig azonban - részben az ágazati szabályozásban meglévő viszonylagos egyensúly, részben a versenyszabályozásban alkalmazott, egyszerübben kezelhető, hüvelykujjszabályokat adó piacelemzési módszerek miatt - a kapcsolat távolságtartó volt.

Az 1970-es évektől azonban számos addig müködő közgazdasági paradigma megdőlt, a szabályozott piacok egyes részpiacairól kiderült, hogy megtámadhatók, a természetes monopóliumok körében bebizonyították, hogy sokkal szükebben értelmezhetők, mint ahogy korábban gondolták, bekövetkezett a szabályozott ágazatok piacának megnyitása. A piacelméletben megerősödött a játékelméleti megközelítés, és a közgazdasági elemzési eszközök fejlődése további helyet követelt a versenyszabályozás területén is.

A jog és közgazdaságtan szorosabbá váló kapcsolata azonban nem volt súrlódásmentes, a bíróságok a munkájukat gyorsító elemzési eszközöket hamar alkalmazták, de a nagyobb perekben az egymással szembeszegülő közgazdasági szakértői álláspontok közötti döntés nehézsége megfontolásra készteti a bíróságokat a szakértők szerepvállalását illetően. A felkészültségben rejlő különbségek csökkentésére mind a jogászok, mind a közgazdászok a másik szakmai alapjainak elsajátításába kezdtek. Mindezek 
eredményeként a szakértői, tanácsadói körben növekedett a két szakma egymásrautaltsága, a piac bővülése miatt a közgazdasági elemzések előtérbe kerülése feltehetően nem rontotta, esetleg javította a jogi tanácsadók piaci helyzetét is.

A jog és közgazdaságtan kapcsolódása, a müködésüket befolyásoló szélesebb társadalmi közeg természetesen sosem volt mentes a politikai befolyásolástól. A legkülönbözőbb irányokból erős a törekvés a versenyszabályozás célrendszerének a módosítására. Többen megkérdőjelezik azt - az Egyesült Államokban a turbulens, ellentmondásos döntéseket hozó időszak után - a 70-es évek bírósági gyakorlatában teret nyert és konszolidált viszonyokat eredményező véleményt, hogy az ügyek végső mérlegét a fogyasztói jólét alakulása szempontjából kell megvonni. A hatékonyság kérdése nem lehet az egyedüli mérlegelési szempont, az anyagi jólétet egyéb, nem anyagi jóléti szempontokkal is ki kellene egészíteni, a javak elosztásának aránytalanságait is figyelembe kellene venni, az egyre több nagyra nőtt vállalat, különösen az új technológiai cégek versenykorlátozó hatását csökkenteni kell, stb. Ezekhez a törekvésekhez társulnak a kormányok, politikai vezetők gyakran direkt beavatkozást követelő nyilatkozatai. ${ }^{40}$ Ezeket az egymásnak is ellentmondó törekvéseket ma „hipszter antitrösztnek” szokták nevezni, ugyanakkor a fenti kérdésekről szakmai viták is folynak. ${ }^{41}$

Az utóbbi években hozott vagy még függőben lévő bírósági ügyek is élénk vitákat váltottak ki. 2018 júniusában az amerikai bíróságokon megszületett két döntés megrázta a versenyügyekben jártas jogász- és közgazdász-társadalmat. Az egyik ügyben (American Express) a bankkártyák miatt a kétoldalú piacok kérdése került a viták középpontjába. ${ }^{42} \mathrm{~A}$ legfelsőbb bíróság döntését úgy értelmezik, hogy a jövőben csak akkor lehet kétoldalú piacokon versenyhátrányt kimutatni, ha az mindkét piacon igazolható. Ezt a közgazdasági elmélet elmúlt húszéves fejlődésével ellentétesnek minősített álláspontot már a per során is neves közgazdászok (köztük Nobel-díjasok: Stiglitz, McFadden) cáfolni próbálták a peren kívüli hozzászólás intézménye (amicus curiae) keretében. ${ }^{43}$ Mivel az internet használatával összefüggő legnagyobb technológiai cégek mind két- (vagy több-) oldalú piacokon müködnek, a kétoldalú piacok kérdése alapvető fontosságúvá vált a versenyügyekben (Evans-Schmalensee [2018]).

A másik ügy (AT\&T-Time Warner) különlegessége az volt, hogy közel negyven év után az Egyesült Államok igazságügy-minisztériuma (Department of Justice, DoJ)

${ }^{40}$ Ennek egyik legjobban dokumentált példája olvasható Stephen Littlechild cikkében (Littlechild [2015]) a brit energiaárak emelkedésének visszafogását célzó politikai törekvésekröl, amelyekben minden politikai oldal egyetértően vett részt, és aminek egyetlen eredménye a súlyos szabályozási anomália lett.

${ }^{41}$ A fogalom Konstantin Medvedovsky 2017-es twitterbejegyzése alapján honosodott meg (Medvedovsky [2018]). Az Antitrust Chronicle 2018. áprilisi teljes száma ezzel a kérdéskörrel foglalkozik (https://www.competitionpolicyinternational.com/wp-content/uploads/2018/05/AC_APRIL. pdf). A Harvard Law School 2018 novemberében a legnevesebb versenyjogászok és versenyközgazdászok részvételével konferenciát szervezett (Challenges to Antitrust in a Changing Economy, https:// coreblog.lexxion.eu/challenges-to-antitrust-in-a-changing-economy).

${ }^{42}$ Ohio et al. v. American Express Co. et al. No. 16-1454.

${ }^{43}$ Brief for Amici Curiae John M. Connor, Martin Gaynor, Daniel McFadden, Roger Noll, Jeffrey M. Perloff, Joseph A. Stiglitz, Lawrence J. White, and Ralph A. Winter in Support of Petitioners. https:// www.researchgate.net/publication/327078908_Brief_for_Amici_Curiae_John_M_Connor_Martin_ Gaynor_Daniel_Mcfadden_Roger_Noll_Jeffrey_M_Perloff_Joseph_A_Stiglitz_Lawrence_J_ White_and_Ralph_A_Winter_in_Support_of_Petitioners_In_the_Supreme_Court_of_. 
először indított vertikális fúzió megtiltása ügyében pert a bíróságokon. A még le nem zárult perben az elsőfokú döntés a fúzió kötelezettségvállalások nélküli engedélyezését hozta, egyben megkérdőjelezte a minisztérium által előadott közgazdasági érvelés érvényességét, azaz, hogy a Nash-egyensúlyi modellek képesek-e a valóságot tükrözni. Ebben az esetben ugyanis a modellvizsgálatok azt mutatták ki, hogy a vertikális összeolvadás a tartalomszolgáltatáshoz való hozzáférést jelentős mértékben nehezíti, ami a piacon általános áremelést okozhat. A perben ismét sor került peren kívüli hozzászólás benyújtására, a modell érvényességét 27 versenyügyekkel foglalkozó tudós (jogász és közgazdász) állította. ${ }^{44} \mathrm{~A}$ közgazdasági érvelés elutasítását a jogi és a társadalomtudományi gondolkodásmód és a felhasznált eszköztár különbözöségével is indokolni próbálják. Ennek a megközelítésnek a tarthatatlanságát fogalmazta meg Jonathan Klick jogászprofesszor több, közgazdászokkal együtt kialakított és a jogi eljárásokban jól bevált tesztre hivatkozva (Klick [2018]).

\section{Létezik-e jogalkalmazási közgazdaságtan?}

Az eddig leírtakból talán érzékelhető, hogy a kérdésre nem tudunk határozott választ adni. Felvázoltuk a forensic economics szókapcsolathoz köthető nézeteket, fogalmi tisztázatlanságot. A piac- és vállalatelmélet fejlődésével párhuzamosan áttekintettük az ágazati és versenyszabályozásban, a versenyjogi bírósági eljárásokban alkalmazott közgazdasági módszereket. Látható volt, hogy a piac- és vállalatelmélet egymást követő közgazdasági iskolái egyre nagyobb hatást gyakoroltak a jogalkalmazásban használható bizonyítási, elemzési eljárásokra, közgazdasági eszköztárakra. A részletes közgazdasági elemzések mellett ugyanakkor erősödő igény támadt a felmerülő jogviták gyors besorolását, az ügyek szürését elősegítő tesztek, közgazdaságilag értelmezhető hüvelykujjszabályok kialakítására. A piac- és vállalatelméletben alkalmazott közgazdasági elemzési módszerek fejlődését viszont nagymértékben serkentették a szabályozási kérdések megoldása során felmerülő problémák. A két terület közötti kölcsönhatás eredményeként egyre nagyobb szerepet kaptak a közgazdasági szakértők, és fokozatosan egy speciális tudást igénylö, a szabályozási és versenyügyekben jártas közgazdasági tanácsadói kör alakult ki.

Míg korábban a forensic economics fogalmát elsősorban a kártérítési ügyekben alkalmazható közgazdasági módszerekre értelmezték, mára többen is bejelentkeztek a szóösszetétel használatára, mint például a gazdasági szereplők rejtett magatartását feltáró közgazdászok. A jelentkezők között a leghatásosabban a piac- és vállalatelmélet hívei érvelnek. Kétségtelen, hogy a piac- és vállalatelmélet területén kevés olyan kérdéskört találnánk, amely nem találkozik a verseny- és ágazati szabályozásban felmerülö kérdésekkel. Azt a kérdést is felvethetnénk, hogy van-e egyáltalán a szabályozás, a jogalkalmazás területétől független piac- és vállalatelmélet, és ha megengedőbbek vagyunk, akkor is az a benyomásunk, hogy akár elméleti, akár empirikus piac- és vállalatelméletről gondolkodunk, annak egyre

\footnotetext{
${ }^{44}$ https://joeharrington5201922.github.io/pdf/Amicus\%20Brief_AT\&T\%20Time\%20Warner.pdf.
} 
nagyobb szelete tartozik ebbe az alkalmazott közgazdaságtani körbe. A szűrők, tesztek, szabályok szürkezónája már egyértelmüen a jogalkalmazás által felvetett kérdésekre adott válasz, az alkalmazás kontextusában születő új ismeret, ahol a teljesítményt is máshogy mérik. Ebben a világban a felhasználók és más szakmabeliek közösen gyakorolják a minősítést. ${ }^{45}$

Ha a jogalkalmazási közgazdaságtan kifejezésnek van létjogosultsága, akkor bizonyosan nemcsak a piac- és vállalatelmélet tartozhat alá, hanem minden olyan közgazdasági aldiszciplína - és ezek jövőbeli köre ma még esetleg nem is látható -, mint a kísérleti közgazdaságtan, a viselkedés-gazdaságtan mindazon területei, amelyekben a jogalkalmazáshoz szállítanak inputokat. Ebben az esetben a forensic kifejezésnek az eredeti értelméhez jutunk vissza, a jogszolgáltatással összefüggő, nyilvánosság előtt zajló és ott megvitatható közgazdaságtan. Ez a kategorizálás azonban nem biztos, hogy megállna a tudományelmélet színe előtt.

\section{Hivatkozások}

Affeldt, P.-Filistucchi, L.-KLein, T. J. [2013]: Upward pricing pressure in two-sided markets. Economic Journal, Vol. 123. No. 572. F505-523. o.

Antal-Pomázi KRisztina [2015]: Közgazdasági szakértők a bírósági eljárásokban. Megjelent: Valentiny Pál-Kiss Ferenc László-Nagy Csongor István (szerk.): Verseny és szabályozás, 2014. MTA KRTK Közgazdaság-tudományi Intézet, Budapest, 125-149. o.

Areeda, P.-Turner, D. F. [1975]: Predatory Pricing and Related Practices under Section 2 of the Sherman Act. Harvard Law Review, Vol. 88. No. 4. 697-733. o. https://doi. org/10.2307/1340237.

Arenson, K. W. [1983]: End of a Bell research role. The New York Times, augusztus 15. http://www.nytimes.com/1983/08/15/business/end-of-a-bell-research-role.html?page wanted $=$ all.

Armstrong, M.-SAppington, D. E. M. [2004]: Toward a Synthesis of Models of Regulatory Policy Design with Limited Information. Journal of Regulatory Economics, Vol. 26. No. 1. 5-21. o. https://doi.org/10.1023/b:rege.0000028011.71612.70.

Armstrong, M.-Wright, J. [2009]: Mobile call termination in the UK: A competitive bottleneck? Megjelent: Lyons, B. (szerk.): Cases in European Competition Policy. The Economic Analysis. Cambridge University Press, Cambridge, 75-99. o. https://doi. org/10.1017/cbo9780511803130.008.

Bagwell, K.-Wolinsky, A. [2002]: Game theory and industrial organization. Megjelent: Aumann, R.-Hart, S. (szerk.): Handbook of Game Theory with Economic Applications. Vol. 3. North -Holland, 1851-1895. o. https://oi.org/10.1016/s1574-0005(02)03012-6.

Bailey, E. M. [2015]: Behavioral Economics and U.S. Antitrust Policy. Review of Industrial Organization, Vol. 47. No. 3. 355-366. o. https://doi.org/10.1007/s11151-015-9469-9.

Baker, J. B.-Bresnahan, T. F. [2008]: Economic Evidence in Antitrust: Defining Markets and Measuring Market Power. Megjelent: Buccirossi, P. (szerk.): Handbook of Antitrust Economics. MIT Press, Cambridge, 1-42. o.

\footnotetext{
${ }^{45} \mathrm{Ez}$ a folyamat nem csak a piac- és vállalatelméletre vonatkoztatható -, a tudományos eredmények születésének és minősítésének új rendszeréről lásd Hemlin-Rasmussen [2006] írását.
} 
Baye, M. R.-Wright, J. D. [2011]: Is Antitrust Too Complicated for Generalist Judges? The Impact of Economic Complexity and Judicial Training on Appeals. Journal of Law \& Economics, Vol. 54. No. 1. 1-24. o. https://doi.org/10.1086/652305.

Beckner, C. F.-SAlop, S. C. [1999]: Decision Theory and Antitrust Rules. Antitrust Law Journal, Vol. 67. No. 1. 41-76. o.

Behringer, S.-Filistrucchi, L. [2015]: Areeda-Turner in Two-Sided Markets. Review of Industrial Organization, Vol. 46. No. 3. 287-306. o. https://doi.org/10.1007/s11151-0159460-5.

Berg, S. V.-Tschirhart, J. [1988]: Natural monopoly regulation. Principles and practice. Cambridge University Press, Cambridge, https://doi.org/10.1017/cbo9780511572067.

Bishop, S.-WALker, M. [2011]: Az európai közösségi versenyjog közgazdaságtana. Alapfogalmak, alkalmazások és mérési módszerek. Gazdasági Versenyhivatal Versenykultúra Központ, Budapest.

Bolton, P.-Brodley, J. F.-Riordan, M. H. [2000]: Predatory Pricing: Strategic Theory and Legal Policy. Georgetown Law Journal, Vol. 88. No. 8. 2238-2330. o.

Borenstein, S. [2016]: The Power and the Limits of Industrial Organization. Review of Industrial Organization, Vol. 48. No. 3. 241-246. o. https://doi.org/10.1007/s11151-016-9508-1.

Boudin, M. [1984]: Forensic Economics. Harvard Law Review, Vol. 97. No. 3. 835-844. o. https://doi.org/10.2307/1340900.

Bresnahan, T. F. [1989]: Empirical Studies of Industries with Market Power. Megjelent: Schmalensee, R.-Willig, R. D. (szerk.): Handbook of Industrial Organization. Vol. 2. NorthHolland, Amszterdam, 1011-1057. o. https://doi.org/10.1016/s1573-448x(89)02005-4.

Budzinski, O. [2011]: Modern Industrial Economics and Competition Policy: Open Problems and Possible Limits. Megjelent: Drexl, J.-Kerber, W.-Podszun, R. (szerk.): Competititon Policy and the Economic Approach. Foundations and Limitations. Edward Elgar, 111-138. o. https://doi.org/10.4337/9780857930330.00013.

Budzinski, O.-Christiansen, A. [2007]: The Oracle/PeopleSoft Case: Unilateral Effects, Simulation Models and Econometrics in Contemporary Merger Control. Marburg Papers on Economics, No. 02.

CABRAL, L. M. B. [2000]: Introduction to Industrial Organization. MIT Press, Cambridge, Mass.

Carlton, D. W. [2011]: Use and Misuse of Empirical Methods in the Economics of Antitrust. CPI Antitrust Chronicle, Vol. 3. No. 1. 1-14. o.

Cavanagh, E. D. [2013]: Antitrust Law and Economic Theory. Finding a Balance. St. John's School of Law Legal Studies Research Paper Series, 13-0006.

Chang, A. C.-Li, P. [2015]: Is Economics Research Replicable? Sixty Published Papers from Thirteen Journals Say “Usually Not”. Finance and Economics Discussion Series, No. 083. Board of Governors of the Federal Reserve System, Washington, http://www.federalreserve. gov/econresdata/feds/2015/files/2015083pap.pdf.

Cherrier, B. [2015]: Classifying Economics: A History of the JEL Codes. Kézirat, http:// papers.ssrn.com/sol3/papers.cfm?abstract_id=2537382.

Comanor, W. S.-Frech, H. E. [2015]: Economic Rationality and the Areeda-Turner Rule. Review of Industrial Organization, Vol. 46. No. 3. 253-268. o. https://doi.org/10.1007/ s11151-015-9457-0.

Connor, J. M. [2008]: Forensic economics: An introduction with special emphasis on price fixing. Journal of Competition Law and Economics, Vol. 4. No. 1. 31-59. o. https://doi. org/10.1093/joclec/nhm022. 
Cooper, J. C.-Kovacic, W. E. [2012]: Behavioral economics: implications for regulatory behavior. Journal of Regulatory Economics, Vol. 41. No. 1.41-58. o. https://doi.org/10.1007/ s11149-011-9180-1.

Crew, M. A.-PARker, D. [2006]: Development in the theory and practice of regulatory ecnomics. Megjelent: Crew, M.-Parker, D. (szerk.): International Handbook on Economic Regulation. Edward Elgar, Cheltenham, 1-33. o. https://doi.org/10.4337/9781847201614.00008.

CSORBA Gergely [2008]: A fúziókontroll módszertanáról. Dominancia- vagy versenyhatásteszt? Megjelent: Valentiny Pál-Kiss Ferenc László (szerk.): Verseny és szabályozás, 2007. MTA Közgazdaság-tudományi Intézet, Budapest, 96-110. o.

Csorba Gergely [2013]: Magyarországi empirikus piacszerkezet-elemzések kutatási eredményeinek és gyakorlati alkalmazásainakáttekintése. Megjelent: Valentiny Pál-Kiss Ferenc László-Nagy Csongor István (szerk.): Verseny és szabályozás, 2012. MTA KRTK Közgazdaság-tudományi Intézet, Budapest, 13-31. o.

Csorba Gergely [2014]: Milyen követelmények érvényesüljenek a versenyjogi ügyek közgazdasági értékelésekor, különösen bírósági felülvizsgálat esetén? Megjelent: Valentiny Pál-Kiss Ferenc László-Nagy Csongor István (szerk.): Verseny és szabályozás, 2013. MTA KRTK Közgazdaság-tudományi Intézet, Budapest, 13-30. o.

Csorba Gergely [2015]: Párhuzamos események értékelése a fúziókontrollban. Megjelent: Valentiny Pál-Kiss Ferenc László-Nagy Csongor István (szerk.): Verseny és szabályozás, 2014. MTA KRTK Közgazdaság-tudományi Intézet, Budapest, 13-27. o.

EAsterbrook, F. H. [1984]: Limits of Antitrust. Texas Law Review, Vol. 63. No. 1. 1-41. o.

Einav, L.-Levin, J. D. [2010]: Empirical Industrial Organization: A Progress Report. Journal of Economic Perspectives, Vol. 24. No. 2. 145-162. o. https://doi.org/10.1257/jep.24.2.145.

Evans, D. S. (szerk.) [1983]: Breaking Up Bell. Essays on Industrial Organization and Regulation. North-Holland, New York.

Evans, D. S.-Fisher, F. M.-Rubinfeld, D. L.-Schmalensee, R. L. [2000]: Did Microsoft Harm Consumers? Two Opposing Views. AEI-Brookings Joint Center for Regulatory Studies, Washington, D. C.

Evans, D. S.-Schmalensee, R. [2018]: Two-sided red herrings. CPI Antitrust Chronicle, október, 2-7. o. https://doi.org/10.2139/ssrn.3261802.

FARrell, J.-Shapiro, C. [2010]: Antitrust evaluation of horizontal mergers: an economic alternative to market definition. B.E. Journal of Theoretical Economics, Vol. 10. No. 1. 1-39. o. https://doi.org/10.2202/1935-1704.1563.

FTC-DoJ [2000]: Antitrust Guidelines for Collaborations Among Competitors. Federal Trade Commission-U. S. Department of Justice, https://www.ftc.gov/sites/default/files/ documents/public_events/joint-venture-hearings-antitrust-guidelines-collaborationamong-competitors/ftcdojguidelines-2.pdf.

GAVIL, A. I. [2007]: The challenges of economic proof in a decentralized and privatized European competition policy system: lessons from the American experience. Journal of Competition Law and Economics, Vol. 4. No. 1. 177-206. o.

Gavil, A. I. [2010]: Defining Reliable Forensic Economics in the Post-Daubert/Kumho Tire Era: Case Studies from Antitrust. Washington and Lee Law Review, Vol. 57. No. 3. 831-878. o.

Ghosal, V. [2008]: The genesis of cartel investigations: Some insights from examining the dynamic interrelationships between U.S. civil and criminal antitrust investigations. Journal of Competition Law and Economics, Vol. 4. No. 1. 61-88. o.

Giocoli, N. [2014]: Games judges don't play: predatory pricing and strategic reasoning in US antitrust. Supreme Court Economic Review, Vol. 21. No. 1.271-330. o. 
Grant, J.-Neven, D. J. [2005]: The attempted merger between General Electric and Honeywell: a case study of transatlantic conflict. Journal of Competition Law and Economics, Vol. 1. No. 3. 595-633. o.

Greene, H. [2006]: Guideline Institutionalization: The Role of Merger Guidelines in Antitrust Discourse. William and Mary Law Review, Vol. 48. No. 3. 770-857. o.

Gual, J.-Hellwig, M. F.-Perrot, A.-Polo, M.-Rey, P.-Schmidt, K. M.-Stenbacka, R. [2005]: An Economic Approach to Article 82. Munich Discussion Paper, No. 2005-26.

Hemlin, S.-Rasmussen, S. B. [2006]: The shift in academic quality control. Journal Science, Technology and Human Values, Vol. 31. No. 2. 173-198. o.

Hildebrand, D. [2009]: The Role of Economic Analysis in the EC Competition Rules. Wolters Kluwer.

Hovenkamp, H. [2015]: The Areeda-Turner Test for Exclusionary Pricing. A Critical Journal. Review of Industrial Organization, Vol. 46. No. 3. 209-228. o.

IDot, L. [2011]: Modern industrial economics revisited. Comment on Daniel Rubinfeld, Michele Polo and Oliver Budzinski. Megjelent: Drexl, J.-Kerber, W.-Podszun, R. (szerk.): Competititon Policy and the Economic Approach. Foundations and Limitations. Edward Elgar, 139-146. o.

IreLAND, T. R. [1997]: The Interface Between Law and Economics and Forensic Economics. Journal of Legal Economics, Vol. 7. No. 1. 60-70. o.

Joskow, P. L.-Klevorick, A. R. [1979]: A Framework for Analyzing Predatory Pricing Policy, Yale Law Journal, Vol. 89. 213-270. o. https://doi.org/10.2307/795837.

KISS FERENC LÁszLó [2008]: Bevezetés a szabályozás gazdaságtanába. Megjelent: Valentiny Pál-Kiss Ferenc László-Nagy Csongor István (szerk.): Verseny és szabályozás, 2007. MTA Közgazdaságtudományi Intézet. Budapest, 11-95. o.

KLICK, J. [2018]: What Should Empirical Legal Economists Do? Journal of Institutional and Theoretical Economics, Vol. 174. No. 1. 29-33 o. https://doi.org/10.1628/0932456 $17 \times 15096094637986$.

LAffont, J. J.-Tirole, J. [1993]: A Theory of Incentives in Procurement and Regulation. MIT Press, Cambridge, MA.

LiAnos, I. [2012]: The emergence of forensic economics in competition law: foundations for a sociological analysis. CLES Working Paper Series, No. 5. http://papers.ssrn.com/sol3/ papers.cfm?abstract_id=2197025.

LitTLECHILD, S. [2015]: The CMA energy market investigation, the well-functioning market, Ofgem, Government and behavioural economics. European Competition Journal, Vol. 11. No. 2-3. 574-636. o. https://doi.org/10.1080/17441056.2016.1153311.

Lőrincz Szabolcs [2010]: Fúzió a holland tejiparban. Megjelent: Valentiny Pál-Kiss Ferenc László-Nagy Csongor István (szerk.): Verseny és szabályozás, 2009. MTA Közgazdaságtudományi Intézet, Budapest, 243-254. o.

MackaAy, E. [2000]: History of Law and Economics. Megjelent: Bouckaert, B.- De Geest, G. (szerk.): Encyclopedia of Law and Economics. Vol. I. The History and Methodology of Law and Economics. Edward Elgar, Cheltenham, 65-117. o.

Medvedovsky, K. [2018]: Hipster Antitrust - A Brief Fling or Something More? CPI Antitrust Chronicle, április 2-7. o.

Markham, J. W., Jr. [2012]: Sailing a sea of doubt. A critique of the rule of reason in U.S. antitrust law. Fordham Journal of Corporate and Financial Law, Vol. 17. No. 3. 593-664. o. MоттA, M. [2007]: Verenypolitika. Elmélet és gyakorlat. Gazdasági Versenyhivatal Versenykultúra Központ, Budapest. 
MоттA, M.-Polo, M. [2003]: Leniency programs and cartel prosecution. International Journal of Industrial Organization, Vol. 21. No. 3. 347-379. o. https://doi.org/10.1016/s01677187(02)00057-7.

MuraKöZy BALÁzs [2015]: Kvantitatív módszerek alkalmazása versenyhatóságok kiemelt ügyeiben, 2009-2013. Megjelent: Valentiny Pál-Kiss Ferenc László-Nagy Csongor István (szerk.): Verseny és szabályozás, 2014. MTA KRTK Közgazdaság-tudományi Intézet, Budapest, 103-124. o.

Neven, D. [2006]: Competition Economics and Antitrust in Europe. Economic Policy, Vol. 21. No. 48. 741-791. o. https://doi.org/10.1111/j.1468-0327.2006.00170.x.

Neven, D.-Mano, M. DE La [2009]: Economics at DG Competition, 2008-2009. Review of Industrial Organization, Vol. 35. No. 4. 317-347. o. https://doi.org/10.1007/s11151-009-9234-Z.

OECD [2008]: Presenting Complex Economic Theories to Judges. OECD Policy Roundtables. http://www.oecd.org/competition/abuse/41776770.pdf.

PAizs LÁszló [2015]: Piaci erő az áramtermelő piacon. Eredmények az egyensúlyi modellezés területéről. Megjelent: Valentiny Pál-Kiss Ferenc László-Nagy Csongor István (szerk.): Verseny és szabályozás, 2014. MTA KRTK Közgazdaság-tudományi Intézet, Budapest, 150-171. o.

Peltzman, S. [1991]: The Handbook of Industrial Organization: Review Article. Journal of Political Economy, Vol. 99. No. 1. 201-217. o. https://doi.org/10.1086/261746.

Phillips, A.-Stevenson, R. E. [1974]: The Historical Development of Industrial Organization. History of Political Economy, Vol. 6. No. 3. 324-342. o. https://doi.org/10.1215/ 00182702-6-3-324.

Pitofsky, R. (szerk.) [2008]: How the Chicago School Overshot the Mark. The Effect of Conservative Economic Analysis on U.S. Antitrust. Oxford University Press, New York. https:// doi.org/10.1093/acprof:oso/9780195372823.003.0005.

Posner, R. A. [1999]: The Law and Economics of the Economic Expert Witness. Journal of Economic Perspectives, Vol. 13. No. 2. 91-99. o. https://doi.org/10.1257/jep.13.2.91.

Price, C. W.-Zhu, M. [2016]: Empirical evidence of consumer response in regulated markets. Journal of Competition Law and Economics, Vol. 12. No. 1. 113-149. o. https://doi. org/10.1093/joclec/nhv041.

Sappington, D. M. E. [2002]: Price regulation. Megjelent: Cave, M.- Majumdar, S.-Vogelsang, I. (szerk.): The handbook of telecommunications economics. Vol. I. Structure, regulation, and competition. Elsevier Science Publishers, Amszterdam, 225-293. o.

SCHINKEL, M. P. [2008]: Forensic Economics in Competition Law Enforcement. Journal of Competition Law and Economics, Vol. 4. No. 1. 1-30. o. https://doi.org/10.1093/joclec/nhm033.

Slottje, D. J. (szerk.) [1999]: The Role of the Academic Economist in Litigation Support. Elsevier Science Publishers, Amszterdam.

Sokol, D. D. [2014]: The Transformation of Vertical Restraints. Per Se Illegality, The Rule of Reason, and Per Se Legality. Antirtust Law Journal, Vol. 79. No. 3. 1003-1016. o.

Spagnolo, G. [2005]: Managerial incentives and collusive behavior. European Economic Review, Vol. 49. No. 6. 1501-1523. o. https://doi.org/10.1016/j.euroecorev.2004.05.003.

Stelzer, I. M. [1991]: Regulatory Methods: A Case for „Hands Across the Atlantic”. Megjelent: Veljanovski, C. (szerk.): Regulators and the Market. Institute of Economic Affairs, London, 59-75. o.

STIGLER, G. J. [1989]: A közgazdászok és a monopólium problémája. Megjelent: Stigler, G. J.: Piac és állami szabályozás. Válogatott tanulmányok. Közgazdasági és Jogi Könyvkiadó, Budapest, 194-214. o. 
Tenn, S.-Froeb, L.-Tschantz, S. [2010]: Mergers when firms compete by choosing both price and promotion. International Journal of Industrial Organization, Vol. 28. No. 6. 695-707. o. https://doi.org/10.1016/j.ijindorg.2010.04.003.

Tirole, J. [1988]: The Theory of Industrial Organization. MIT Press, Cambridge, Mass.

Tirole, J. [2011]: Payment Card Regulation and the Use of Economic Analysis in Antitrust. Competition Policy International, Vol. 7. No. 1. 137-158. o.

Tirole, J. [2015]: Market Failures and Public Policy. American Economic Review, Vol. 105. No. 6. 1665-1682. o. https://doi.org/10.1257/aer.15000024.

Töвöк ÁрÁм [2011]: A dominanciaproblémák tényeinek értelmezése és a közgazdaságtudományi módszertan. Közgazdasági Szemle, 68. évf. 1. sz. 41-55. o.

VALENTINy PÁL [2004]: Árprés és felfaló árazás. Közgazdasági elmélet, bírói, szabályozói gyakorlat. Közgazdasági Szemle, 51. évf. 1. sz. 24-45. o.

VAlentiny PÁl [2008]: A hálózatos közszolgáltatások szabályozási reformjáról. Megjelent: Valentiny Pál-Kiss Ferenc László (szerk.): Verseny és szabályozás, 2007. MTA Közgazdaságtudományi Intézet, Budapest, 231-251. o.

VALENTINy PÁL [2011]: Árukapcsolás és csomagban történő értékesítés: jogesetek és közgazdasági elmélet. Külgazdaság, 55. évf. 7-8. sz. 79-107. o.

VAlentiny PÁl [2018]: Coase-kép másképp: középpontban a közszolgáltatások. Közgazdasági Szemle, 65. évf. 4. sz. 346-381. o. https://doi.org/10.18414/ksz.2018.4.346.

VAlentiny PÁL-Kiss Károly Miklós [2009]: A nélkülözhetetlen eszközök értelmezése és a postai szolgáltatások. Közgazdasági Szemle, 56. évf. 11. sz. 1001-1024. o.

Vernon, J. M.-Viscusi, W. K.-Harrington, J. E. JR., [1995]: Economics of Regulation and Antitrust. Second Edition, MIT Press, Cambridge.

Vickers, J. [2007]: Competition Law and Economics. A Mid-Atlantic Viewpoint. European Competition Journal, Vol. 3. No. 1. 1-15. o. https://doi.org/10.5235/ecj.v3n1.1.

VINCZE JÁnOs [2012]: Fogyasztóvédelem a pénzügyi piacokon és a viselkedés-gazdaságtan. Megjelent: Valentiny Pál-Kiss Ferenc László-Nagy Csongor István (szerk.): Verseny és szabályozás, 2011. MTA KRTK Közgazdaság-tudományi Intézet, Budapest, 239-258. o.

Werden, G. J.-Froeb, L. M. [2008]: Unilateral Competitive Effects of Horizontal Mergers. Megjelent: Buccirossi, P. (szerk.): Handbook of Antitrust Economics. MIT Press, Cambridge, 43-114. $\mathrm{o}$.

White, L. [2010]: The Growing Influence of Economics and Economists on Antitrust: an Extended Discussion. Economics, Management, and Financial Markets, Vol. 5. No. 1. 25-63. o. https://doi.org/10.2139/ssrn.1091531.

Wright, J. [2009]: Overshot the Mark? A Simple Explanation of the Chicago School's Influence on Antitrust. Competition Policy International, Vol. 5. No. 1. 1-34. o.

Wright, J. D.-Diveley, A. M. [2013]: Do expert agencies outperform generalist judges? Some preliminary evidence from the Federal Trade Commission. Journal of Antitrust Enforcement, Vol. 1. No. 1. 82-103. o. https://doi.org/10.1093/jaenfo/jns007.

Zitzewitz, E. [2012]: Forensic Economics. Journal of Economic Literature, Vol. 50. No. 3. 731-769. o. https://doi.org/10.1257/jel.50.3.731. 